\title{
Vascular Normalization as a Therapeutic Strategy for Malignant and Nonmalignant Disease
}

\author{
Shom Goel, Andus Hon-Kit Wong, and Rakesh K. Jain \\ Edwin Steele Laboratory for Tumor Biology, Department of Radiation Oncology, Massachusetts \\ General Hospital, Boston, Massachusetts 02114 \\ Correspondence: jain@steele.mgh.harvard.edu
}

Pathological angiogenesis—driven by an imbalance of pro- and antiangiogenic signaling —is a hallmark of many diseases, both malignant and benign. Unlike in the healthy adult in which angiogenesis is tightly regulated, such diseases are characterized by uncontrolled new vessel formation, resulting in a microvascular network characterized by vessel immaturity, with profound structural and functional abnormalities. The consequence of these abnormalities is further modification of the microenvironment, often serving to fuel disease progression and attenuate response to conventional therapies. In this article, we present the "vascular normalization" hypothesis, which states that antiangiogenic therapy, by restoring the balance between pro- and antiangiogenic signaling, can induce a more structurally and functionally normal vasculature in a variety of diseases. We present the preclinical and clinical evidence supporting this concept and discuss how it has contributed to successful treatment of both solid tumors and several benign conditions.

$T^{\text {he }}$ he successful functioning of all tissues depends on the establishment of a hierarchically structured, mature vascular network. As such, the development of new blood vesselsangiogenesis-plays a critical role in healthy human development. Angiogenesis in the human is most vibrant during embryogenesis and is relatively suppressed in the adult. It is usually a tightly regulated process, triggered by specific molecular and mechanical stimuli to meet the needs of the host and suppressed again by antagonistic stimuli when these needs have been met.

In contrast to the healthy state, a number of human diseases show a dysregulated excess of new blood vessel formation. Solid tumors are the best characterized example, with seminal work first performed more than 70 years ago confirming the importance of an abundant blood supply for tumor growth (Ide et al. 1939; Algire and Chalkley 1945). Unlike physiological angiogenesis, blood vessel development in solid tumors is not tightly controlled, but rather occurs relentlessly (Dvorak 1986; Chung et al. 2010; Carmeliet and Jain 2011). Molecular stimuli within solid tumors (hypoxia, acidosis, oncogenic signaling, growth factors, sex hormones, and cytokines) all induce the formation of new vessels (Vogelstein and Kinzler 2004; Ferrara 2005; Carmeliet and Jain 2011). Although the main purpose of such stimuli is to ensure a rich vascular supply for

Editors: Michael Klagsbrun and Patricia D'Amore

Additional Perspectives on Angiogenesis available at www.perspectivesinmedicine.org

Copyright (C) 2012 Cold Spring Harbor Laboratory Press; all rights reserved; doi: 10.1101/cshperspect.a006486

Cite this article as Cold Spring Harb Perspect Med 2012;2:a006486 
S. Goel et al.

continuing tumor growth, the unyielding drive for angiogenesis results in a vascular network that is highly abnormal when compared to the organized structure of vessel networks in normal tissues (Jain 2005a, 2008). This structurally abnormal network leads to aberrations in local blood flow, fluid dynamics, and oxygenation that in turn can augment tumor growth and metastatic potential while diminishing response to cytotoxic therapies (Jain 2001, 2005b). More recently, similar abnormalities in vessel structure and function have been reported in a number of nonmalignant diseases (Carmeliet and Jain 2011; Goel et al. 2011). In each of these examples, disease progression is influenced by abnormalities in the microvasculature and the resultant abnormal microenvironment.

The discovery of vascular endothelial growth factor (VEGF) as the principal driver of tumor angiogenesis (Senger et al. 1983; Leung et al. 1989) rapidly prompted the development of antiangiogenic drugs to treat cancer, designed to inhibit VEGF's activity and hence promote vascular regression and tumor starvation (Folkman 1971; Kim et al. 1993). This rationale was supported by early preclinical trials demonstrating growth delays in mouse models of solid cancers after treatment with anti-VEGF antibodies (Kim et al. 1993). Unfortunately, results using such agents in clinical trials have been disappointing, with antiangiogenic monotherapy generally failing to invoke significant response rates or prolongations of survival in solid tumor patients (Jain et al. 2006; Giantonio et al. 2007). Indeed, clinical data suggest that anti-VEGF therapy cannot induce sustained shrinkage in human tumors such as breast and colorectal cancer. Intriguingly, however, the addition of anti-VEGF therapy to systemic chemotherapy has often proven to be an effective strategy, with patient outcomes superior to chemotherapy alone (Hurwitz et al. 2004; Sandler et al. 2006; Miller et al. 2007; Saltz et al. 2008; Reck et al. 2009). This suggests that although antiangiogenic therapies may not "starve" tumors in patients, they do in some way enhance the activity of cytotoxics - an intuitively paradoxical observation given that the efficacy of chemotherapy depends on the presence of an adequate tumor blood supply to ensure drug delivery. The "vascular normalization" hypothesis is a potential resolution of this paradox.

In this article, we present the vascular normalization hypothesis, which we first introduced in 2001 (Jain 2001). This hypothesis posits that rather than obliterating vessels, the judicious use of antiangiogenic therapy prunes some vessels and reverts the grossly abnormal structure and function of the remaining vasculature toward a more normal state, abrogating its deleterious effects on the tumor microenvironment. We summarize the preclinical and clinical studies providing evidence in support of this hypothesis. In addition, we discuss the nature of vascular abnormalities in nonmalignant disease, and possible benefits from normalizing these. We also present recent findings that have shed light on the key molecular players regulating the switch between a "normal" and "abnormal" microvessel phenotype, furthering the mechanistic understanding of vascular normalization.

\section{VASCULAR ABNORMALITIES IN SOLID TUMORS}

Solid tumors should be considered as entire "organs" in themselves. Much more than a mass of proliferating cancer cells, a tumor is an assembly of cancer cells, a blood vessel network, lymphatic vessels, and a variety of other cells all of which contribute to the local microenvironment. Angiogenesis within solid tumors is driven largely by hypoxia. This hypoxia, a hallmark of the tumor microenvironment, leads directly to the production of proangiogenic factors such as VEGF via modulation of oxygen sensing molecules (Semenza 2010). In addition, VEGF production in tumors is also fuelled by acidosis, activation of cellular oncogenes that lie upstream of VEGF, inflammatory cytokines, growth factors, and protumorigenic sex hormones (Vogelstein and Kinzler 2004; Ferrara 2005; Carmeliet and Jain 2011).

The microenvironmental abundance of VEGF and other proangiogenic factors drives 
continual angiogenesis and the production of an abnormal blood vessel network (Jain 2005a; Nagy et al. 2009). Structurally, vessels are often dilated, weave a tortuous path, and show heterogeneity of distribution such that certain areas within a tumor are hypovascular and others hypervascular (Less et al. 1991, 1997; Yuan et al. 1996; Tong et al. 2004; Jain 2005b; Baish et al. 2011). At the cellular level, proangiogenic factors induce weakening of VE-Cadherin-mediated endothelial cell (EC) junctions and EC migration, altering vessel wall architecture (Hobbs et al. 1998; Hashizume et al. 2000). Similarly, the perivascular cells (PVCs, comprised of pericytes and vascular smooth muscle cells [VSMCs]) are often only loosely attached to ECs and are reduced in number (Morikawa et al. 2002; Abramsson et al. 2003; Jain 2003; Inai et al. 2004; Tong et al. 2004). A number of important molecules regulate pericyte-EC interaction, including platelet-derived growth factor-B (PDGF-B), Ang-1, transforming growth factor- $\beta$ (TGF- $\beta$ ), and sphingosine-1-phosphate (S1P) in healthy tissues (Jain 2003; Jain and Booth 2003). In tumors, proangiogenic factors promote PVCEC dissociation, however. For example, VEGF induces the formation of VEGFR-PDGFR $\beta$ complexes in pericytes, which impede PDGFR $\beta$ mediated adherence of ECs to pericytes (Greenberg et al. 2008). Finally, the perivascular basement membrane (BM) is also structurally abnormal in tumors - excessively thin or absent in certain regions and abnormally thick in others (Inai et al. 2004; Tong et al. 2004; Winkler et al. 2004; Kamoun et al. 2009).

A direct consequence of these structural derangements is marked aberration of tumor vascular function. The haphazard and bizarre distribution of vessels leads to heterogeneous blood flow, sluggish in some regions and excessive in others (Jain 1988, 2005b; Kamoun et al. 2010). In addition, reduced PVC coverage, EC dissociation, and an excess of vesiculo-vaculor organelles (VVOs) results in marked tumor vessel permeability, with excess extravasation of fluid and protein into the extracellular compartment (Jain 2005b). This leakiness, together with a relative absence of functional intratumoral lymphatic vessels (Padera et al. 2004; Hagendoorn et al. 2006), leads to a marked increase in the tumor interstitial fluid pressure (IFP) to a level that equilibrates with intravascular pressure, which results in reduced transvascular flow (Boucher et al. 1990, 1991; Roh et al. 1991; Less et al. 1992; Leunig et al. 1992; Stohrer et al. 2000; Tong et al. 2004; Willett et al. 2004). Furthermore, the compressive forces applied by the proliferating mass of cancer cells can cause vascular compression and collapse (Padera et al. 2004). The net result is a heterogeneous blood supply, and resultant hypoxia and acidosis (Jain 2005b).

The physiological changes described have a direct effect on solid tumor behavior. Hypoxic tumor cells often show a more aggressive phenotype, activating oncogenes and passing through an "epithelial to mesenchymal transition" (EMT), which heightens their metastatic potential (DeClerck and Elble 2010). Moreover, the hostile microenvironment impairs the function of antitumor immune cells, the delivery of which into the tumor is also impaired (Hamzah et al. 2008). Importantly, tumor response to therapy is also impacted. Hypoxia is known to reduce tumor cell sensitivity to radiation and chemotherapy (Teicher 1996), and the delivery of systemically administered cytotoxics into tumors is dramatically impeded, especially in areas of low blood flow and raised tumor IFP (Jain 1989; Wildiers et al. 2003; Tong et al. 2004). It is thus clear that tumor angiogenesis fuels a cascade of microenvironmental abnormalities which can hinder therapeutic outcomes. Reversal of these abnormalities, achieved through "normalizing" tumor vessels, is therefore an intuitively attractive proposition.

\section{THE VASCULAR NORMALIZATION HYPOTHESIS}

The vascular abnormalities in tumors stem from an imbalance between proangiogenic and antiangiogenic factors in the local milieu (Jain 2005b). The "vascular normalization" hypothesis states that direct or indirect antiangiogenic therapy (usually therapy aimed to 
S. Goel et al.

A

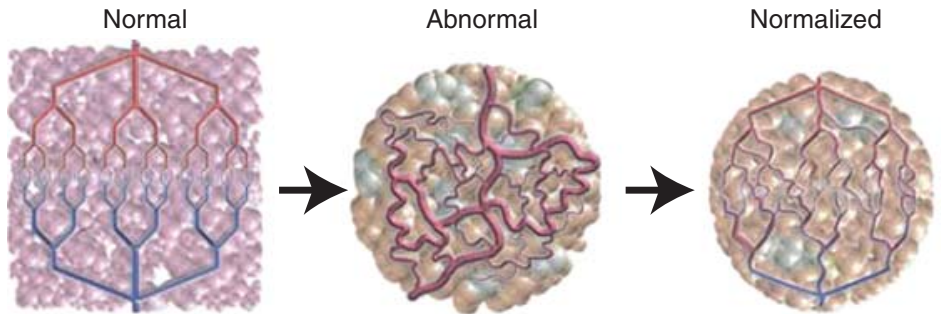

B
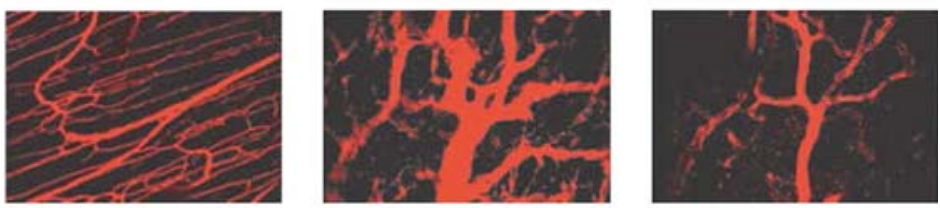

C
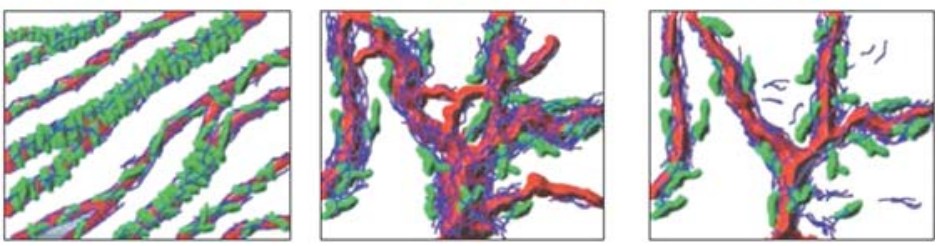

D
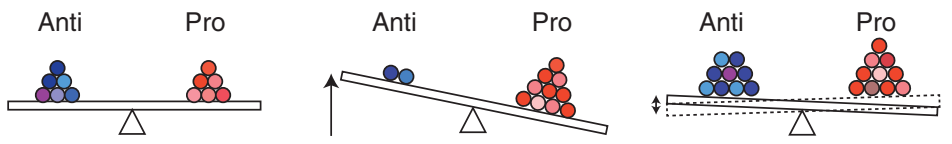

Figure 1. Proposed role of vessel normalization in the response of tumors to antiangiogenic therapy. (A) Tumor vasculature is structurally and functionally abnormal. It is proposed that antiangiogenic therapies initially improve both the structure and the function of tumor vessels. However, sustained or aggressive antiangiogenic regimens may eventually prune away these vessels, resulting in a vasculature that is both resistant to further treatment and inadequate for the delivery of drugs or oxygen. (B) Dynamics of vascular normalization induced by VEGFR2 blockade. On the left is a two-photon image showing normal blood vessels in skeletal muscle; subsequent images show human colon carcinoma vasculature in mice at day 0 and day 3 after administration of VEGR2-specific antibody. (C) Diagram depicting the concomitant changes in pericyte (green) and basement membrane (blue) coverage during vascular normalization. $(D)$ These phenotypic changes in the vasculature may reflect changes in the balance of pro- and antiangiogenic factors in the tissue. (Figure adapted from Jain 2005; reprinted with permission from the American Association for the Advancement of Science (C) 2005.)

neutralize VEGF activity) tips the imbalance between pro- and antiangiogenic factors back toward equilibrium (Fig. 1). As a result, vessel structure and function become more normal: vessels are more mature with enhanced PVC coverage, blood flow is more homogeneous, vessel permeability and hypoxia are reduced, and importantly the delivery of systemically administered anticancer therapies into tumors is more uniform. This concept explains why antiangiogenic therapy's benefit has often been observed when it is given with chemotherapy (Table 1; Jain 2001, 2005b).

\section{EVIDENCE FOR VASCULAR NORMALIZATION IN TUMORS}

\section{Preclinical Evidence}

Since we proposed the normalization concept, a large number of preclinical studies have confirmed the presence of the "normalized" vessel phenotype through restoring equilibrium between pro- and antiangiogenic signaling: either through suppression of angiogenic factors or enhancement of antiangiogenic activity (Table 2). As discussed below, many 
Vascular Normalization

Table 1. Actual and potential therapeutic benefits of vascular normalization in solid tumors

\begin{tabular}{|c|c|c|}
\hline Therapy & Benefits & Comments \\
\hline \multirow[t]{4}{*}{$\begin{array}{l}\text { Antiangiogenic } \\
\text { monotherapy }\end{array}$} & Reduction in tumor-associated edema ${ }^{a}$ & $\begin{array}{l}\text { Benefit maximized for intracranial } \\
\text { tumors (primary tumors and } \\
\text { brain metastases) }\end{array}$ \\
\hline & $\begin{array}{l}\text { Fewer metastases because of a reduction in } \\
\text { primary tumor cell shedding into the } \\
\text { circulation }^{\text {b }}\end{array}$ & $\begin{array}{l}\text { Showed in genetic models but not } \\
\text { with pharmacologic } \\
\text { normalization }^{c}\end{array}$ \\
\hline & $\begin{array}{l}\text { Fewer metastases because of reduced } \\
\text { hypoxia and hence a reduction in } \mathrm{EMT}^{\mathrm{d}}\end{array}$ & $\begin{array}{l}\text { Showed in genetic models but not } \\
\text { with pharmacologic } \\
\text { normalization }^{\mathrm{c}}\end{array}$ \\
\hline & $\begin{array}{l}\text { Improved infiltration of native antitumor } \\
\text { immune cells } \mathrm{s}^{\mathrm{e}}\end{array}$ & \\
\hline $\begin{array}{l}\text { Antiangiogenic therapy } \\
\text { plus radiotherapy }\end{array}$ & Improved tumor control $^{\mathrm{f}}$ & $\begin{array}{l}\text { Radiotherapy should be given during } \\
\text { the normalization window when } \\
\text { hypoxia is reduced }\end{array}$ \\
\hline $\begin{array}{l}\text { Antiangiogenic therapy } \\
\text { plus systemic } \\
\text { chemotherapy }\end{array}$ & $\begin{array}{l}\text { Improved tumor control because of } \\
\text { increased drug delivery into tumors }\end{array}$ & $\begin{array}{l}\text { Showed preclinically but limited } \\
\text { clinical evidence to date }\end{array}$ \\
\hline $\begin{array}{l}\text { Antiangiogenic therapy } \\
\text { plus immunotherapy }\end{array}$ & $\begin{array}{l}\text { Improved tumor control because of } \\
\text { increased immune cell infiltration } \\
\text { and normalization of the } \\
\text { microenvironment }{ }^{\mathrm{h}}\end{array}$ & $\begin{array}{l}\text { Showed preclinically but limited } \\
\text { clinical evidence to date }\end{array}$ \\
\hline $\begin{array}{l}\text { Abbreviations: EMT, epit] } \\
{ }^{a} \text { Kamoun et al. } 2009 . \\
{ }^{b} \text { Xian et al. 2006; McCart } \\
{ }^{\mathrm{c}} \text { This is controversial give }\end{array}$ & $\begin{array}{l}\text { lial-to-mesenchymal transition. } \\
\text { et al. 2007; Mazzone et al. } 2009 \text {. } \\
\text { recent reports of increased metastasis after antiang }\end{array}$ & logenic therapy in certain animal models \\
\hline \multicolumn{3}{|c|}{ (Ebos et al. 2009; Paez-Ribes et al. 2009). } \\
\hline \multicolumn{3}{|l|}{${ }^{\mathrm{d}}$ Mazzone et al. 2009.} \\
\hline \multicolumn{3}{|c|}{${ }^{\mathrm{e}}$ Griffioen et al. 1996; Dirkx et al. 2006.} \\
\hline \multicolumn{3}{|c|}{$\begin{array}{l}{ }^{f} \text { Gorski et al. 1999; Hansen-Algenstaedt et al. 2000; Lee et al. 2000; Kozin et al. 2001; Ader et al. 2003; Winkler et al. 2004; } \\
\text { Ansiaux et al. 2005, 2006; Pore et al. 2006a; Dings et al. 2007; Kashiwagi et al. 2008; Batra et al. 2009; Cerniglia et al. 2009; } \\
\text { Tsukada et al. 2009; McGee et al. 2010. }\end{array}$} \\
\hline
\end{tabular}

studies testing the effects of antiangiogenic drugs have shown a presence of a "normalization window" - a time period beginning with the appearance of a normalized vascular phenotype (typically within 1-2 days of starting treatment), and ending when features of normalization are lost (Tong et al. 2004; Winkler et al. 2004; Jain 2005b; Batchelor et al. 2007; Kamoun et al. 2009). The window's closure may be caused by excessively high or prolonged dosing of antiangiogenics (tipping the balance in favor of antiangiogenic factors and hence leading to vascular regression), or because of the emergence of resistance to antiangiogenic therapy, in which tumors recruit vessels via alternate modes. The concept of normalization of tumor vessels has evolved dramatically over time. Interestingly, many genetic studies have not shown this window but rather show prolonged maintenance of vascular normalization (e.g., see Mazzone et al. 2009). Whether this can be realized using pharmacological agents is an open question. Nonetheless, these studies have provided exciting insights into the molecular underpinnings of vessel structure and function in solid tumors, and give hope for the strategic design of therapies giving rise to enduring normalization. In this 
S. Goel et al.

Table 2. The number of preclinical studies demonstrating features of vascular normalization in the published literature

\begin{tabular}{lccrr}
\hline & $\begin{array}{c}\text { Direct } \\
\text { antiangiogenics }\end{array}$ & $\begin{array}{c}\text { Indirect } \\
\text { antiangiogenics }\end{array}$ & $\begin{array}{c}\text { Genetic } \\
\text { models }\end{array}$ & Total \\
\hline Structure & & & $5^{\mathrm{c}}$ & $\mathbf{1 9}$ \\
$\quad$ Reduced vessel diameter & $10^{\mathrm{a}}$ & $4^{\mathrm{b}}$ & $13^{\mathrm{f}}$ & $\mathbf{3 0}$ \\
$\quad$ Increased pericyte coverage/proximity & $14^{\mathrm{d}}$ & 0 & $1^{\mathrm{h}}$ & $\mathbf{6}$ \\
$\quad 5^{\mathrm{g}}$ & & $12^{\mathrm{j}}$ & $9^{\mathrm{k}}$ & $\mathbf{3 0}$ \\
Function & $9^{\mathrm{i}}$ & $8^{\mathrm{m}}$ & $5^{\mathrm{n}}$ & $\mathbf{2 5}$ \\
$\quad$ Improved oxygenation & $12^{\mathrm{l}}$ & $5^{\mathrm{p}}$ & $3^{\mathrm{q}}$ & $\mathbf{1 6}$ \\
$\quad$ Reduced permeability/IFP & $8^{\mathrm{o}}$ & & & \\
$\quad$ Improved delivery of drugs or & & &
\end{tabular}

${ }^{a}$ Yuan et al. 1996; Tong et al. 2004; Dickson et al. 2007b; Taguchi et al. 2008; Falcon et al. 2009; Juan et al. 2009; Kamoun et al. 2009; Chae et al. 2010; Koh et al. 2010; Primo et al. 2010.

bJain et al. 1998; Izumi et al. 2002; Delmas et al. 2003; Qayum et al. 2009.

${ }^{c}$ Hamzah et al. 2008; di Tomaso et al. 2009; Nasarre et al. 2009; Van de Veire et al. 2010; Rolny et al. 2011.

dinai et al. 2004; Tong et al. 2004; Nakahara et al. 2006; Dickson et al. 2007b; Dings et al. 2007; Fischer et al. 2007; Zhou et al. 2008; Falcon et al. 2009; Juan et al. 2009; Kamoun et al. 2009; Ohta et al. 2009; Zhou and Gallo 2009; Chae et al. 2010; Primo et al. 2010 .

${ }^{\mathrm{e} S}$ Salnikov et al. 2005; Bhattacharya et al. 2008; Qayum et al. 2009.

${ }^{\mathrm{f} B e n j a m i n}$ et al. 1999; Dickson et al. 2007a,c; Greenberg et al. 2008; Hamzah et al. 2008; Kashiwagi et al. 2008; Stockmann et al. 2008; di Tomaso et al. 2009; Maione et al. 2009; Mazzone et al. 2009; Nasarre et al. 2009; Rolny et al. 2011; J Liu, S Liao, B Diop-Frimpong, et al., unpubl. data.

${ }^{\mathrm{g}}$ Tong et al. 2004; Winkler et al. 2004; Zhou et al. 2008; Kamoun et al. 2009; Zhou and Gallo 2009.

${ }^{\mathrm{h}}$ Mazzone et al. 2009.

${ }^{\mathrm{i}}$ Hansen-Algenstaedt et al. 2000; Lee et al. 2000; Winkler et al. 2004; Dings et al. 2007; Fischer et al. 2007; Eichhorn et al. 2008; Batra et al. 2009; Skuli et al. 2009; McGee et al. 2010.

${ }^{j}$ Teicher et al. 1995b; Jain et al. 1998; Bernsen et al. 1999; Cohen-Jonathan et al. 2001; Delmas et al. 2003; Ansiaux et al. 2005, 2006; Pore et al. 2006b; Segers et al. 2006; Cerniglia et al. 2009; Qayum et al. 2009; Cham et al. 2010.

kAder et al. 2003; Hamzah et al. 2008; Kashiwagi et al. 2008; Stockmann et al. 2008; Maione et al. 2009; Mazzone et al. 2009; Skuli et al. 2009; Tsukada et al. 2009; Rolny et al. 2011.

${ }^{\text {l} Y u a n ~ e t ~ a l . ~ 1996 ; ~ L e e ~ e t ~ a l . ~ 2000 ; ~ W i l d i e r s ~ e t ~ a l . ~ 2003 ; ~ T o n g ~ e t ~ a l . ~ 2004 ; ~ N a k a h a r a ~ e t ~ a l . ~ 2006 ; ~ D i c k s o n ~ e t ~ a l . ~ 2007 b ; ~ K u r o z u m i ~}$ et al. 2007; Taguchi et al. 2008; Zhou et al. 2008; Kamoun et al. 2009; Ohta et al. 2009; Zhou and Gallo 2009.

${ }^{m}$ Jain et al. 1998; Izumi et al. 2002; Ansiaux et al. 2005; Salnikov et al. 2005; Bhattacharya et al. 2008, 2009; Schnell et al. 2008; Cerniglia et al. 2009.

${ }^{\mathrm{n}}$ Dickson et al. 2007c; Kashiwagi et al. 2008; di Tomaso et al. 2009; Mazzone et al. 2009; Rolny et al. 2011.

${ }^{\circ}$ Wildiers et al. 2003; Tong et al. 2004; Nakahara et al. 2006; Dickson et al. 2007b; Kurozumi et al. 2007; Zhou et al. 2008; Juan et al. 2009; Zhou and Gallo 2009.

PTeicher et al. 1995a,b; Segers et al. 2006; Bhattacharya et al. 2008, 2009.

${ }^{\mathrm{q}}$ Dickson et al. 2007a,c; J Liu, S Liao, B Diop-Frimpong, et al., unpubl. data.

section, we discuss the key molecules implicated in tumor vessel biology with a focus on their role in regulating vascular normalization.

\section{VEGF}

To date, all therapies approved as treatment for solid tumors target the proangiogenic action of VEGF. Preclinical studies have used a number of approaches including (1) specific VEGF blockade with agents that interfere with VEGF binding to its receptors (including antihuman VEGF antibodies such as A4.6.1 and bevacizumab), antimurine VEGF antibodies, and the "VEGF-Trap" aflibercept; (2) inhibition of VEGFR2 function (using anti-VEGFR2 antibodies such as DC101 or receptor tyrosine kinase inhibitors [TKIs] which inhibit the kinase domain of VEGFRs). In addition, elegant preclinical work examining the role of 
VEGF has come from genetic studies, which provide a cleaner understanding of the effect of a single factor in specific cell populations, and include inducible and/or conditional models.

Our laboratory provided the first evidence of vascular normalization in response to VEGF blockade in 1996 (Yuan et al. 1996). We examined the effects of A4.6.1 therapy on various different human tumor types implanted in mice under surgically created transparent windows, allowing serial microscopic and dynamic imaging of the tumor vessels' structure and function in real time. Vascular diameter and tortuosity were both reduced after a single dose of A4.6.1, accompanied by a drop in permeability. These changes were dynamic and reversible, and permeability rose to baseline again 5 days after treatment (Yuan et al. 1996). If therapy was continued, however, features of normalization were soon replaced by marked vascular regression, likely because of excessive neutralization of VEGF activity. These findings provided early evidence that neutralization of tumor-cell-derived VEGF could reverse, albeit transiently, some of the abnormalities of the tumor microvasculature.

Since this report, a vast array of studies has explored changes in vessel structure and function in response to VEGF blockade in greater detail. Structural changes such as reduced vessel density have been consistently observed with anti-VEGF antibody therapy and aflibercept in a wide variety of tumor models (Hansen-Algenstaedt et al. 2000; Lee et al. 2000; Wildiers et al. 2003; Inai et al. 2004; Tong et al. 2004; Dickson et al. 2007b; Juan et al. 2009). This has generally been accompanied by an increase in vascular maturity (the proportion of PVC-covered vessels), such that the treated vasculature resembles that of normal tissue more closely (Yuan et al. 1996; Inai et al. 2004; Tong et al. 2004; Dickson et al. 2007b). In some reports, another abnormal feature of tumor vessels - the haphazard and disorganized basement membrane-was also normalized after anti-VEGF therapy (Tong et al. 2004; Winkler et al. 2004; Kamoun et al. 2009).

These structural changes are often accompanied by normalization of vessel function.
Antibody therapy against the VEGF-VEGFR pathway has been shown to reduce vessel permeability, lowering intratumoral IFP, and improving perfusion (Table 2 ). This can reduce tumor hypoxia improving tumor radiosensitivity (Gorski et al. 1999; Lee et al. 2000; Winkler et al. 2004; Dings et al. 2007), improve penetration of large molecules into the tumor interstitium (Tong et al. 2004), and heighten delivery of systemically administered chemotherapeutics into tumors (Wildiers et al. 2003; Dickson et al. 2007b). Of interest, anti-VEGF antibody therapy in melanoma models has also been shown to improve the function of tumor immunotherapy, by facilitating increased delivery of antitumor cytotoxic $\mathrm{T}$ cells into the tumor parenchyma (Shrimali et al. 2010).

Such studies have highlighted the presence of the normalization window, and emphasized its therapeutic importance. In many cases, normalization after VEGF blockade is first noted within hours to days of therapy commencement, and is short-lived (lasting for 7-10 days) (Winkler et al. 2004). It is during this window period that enhanced radiotherapy sensitivity (and hence tumor control) is attained (Winkler et al. 2004). Other groups have shown similar principles with chemotherapy, showing improved tumor control with combined cytotoxics and anti-VEGF agents in a scheduledependent manner (i.e., chemotherapy delivery and tumor control are optimized if chemotherapy is given during the normalization window) (Table 1).

As opposed to antibodies, VEGFR TKI's work at an intracellular level and all have some nonspecific "off-target" binding to other members of the kinome including those present in tumor cells. As a result, mechanistic interpretation of their effects on tumors is more difficult. Although almost all initial clinical trials combining chemotherapy with TKIs yielded disappointing results, recent success from this approach has been reported in a randomized phase 3 trial using an anti-VEGFR TKI with low inhibitory potency (Herbst et al. 2010). Moreover, structural aspects of normalization has been observed in preclinical studies after VEGFR TKI therapy including reduction in 
S. Goel et al.

vessel density, increased vessel maturity, and a tighter proximity of PVCs to ECs (Table 2). In addition, basement membrane abnormalities can also be partially restored in models of GBM treated the anti-VEGFR TKI cediranib (Kamoun et al. 2009). Similarly, functional alterations including reduced vessel permeability and IFP, increased blood flow, improved delivery of systemically administered antibodies and chemotherapy, and increased oxygenation and radiosensitivity have been reported (Table 2 ). In studies of GBM treated with the TKI sunitinib, chemotherapy delivery into tumors was correlated directly with the extent to which features of vascular normalization were attained (Zhou and Gallo 2009).

One important finding of translational relevance is that by reducing vessel leakiness, anti-VEGF therapy can reduce tumor-associated edema. This is particularly important for brain tumors, in which the tight confines of the intracranial space provide marked spatial limitations. Indeed, the anti-VEGFR TKI cediranib, when given to mice with GBM is able to prolong survival dramatically purely though this mechanism. Although no reduction in tumor growth is observed, the reduction in edema delays a precipitous increase in intracranial pressure (Kamoun et al. 2009).

Studies employing genetic models shed further light onto mechanisms behind vessel normalization. When $V E G F^{-/-}$tumors are grown in wild-type animals, tumor vessels show improved PVC coverage (Greenberg et al. 2008). Similarly, when wild-type tumors are grown in mice with a $V E G F^{-/-}$myeloid cell population, tumors again show greater vessel maturity, reduced hypoxia, and chemosensitivity (Stockmann et al. 2008). It thus appears that VEGF-induced vascular normalization is a generalized phenotype, regardless of the source of VEGF.

Several important lessons arise from the above reports, which also give rise to further unanswered questions. First is the potential importance of judicious dosing of anti-VEGF therapy (i.e., doses high enough to reverse vessel abnormalities but not so high as to cause excessive vessel regression). Given that normalization depends on achieving a balance between pro and antiangiogenic factors, this concept is somewhat intuitive but has been emphasized particularly in studies of sunitinib treatment of GBM in which only low (but not high) doses of anti-VEGF treatment improved chemotherapy delivery into tumors (Zhou et al. 2008; Zhou and Gallo 2009). Second, certain molecular mechanisms of anti-VEGF therapymediated normalization have been uncovered. For example, in the case of GBM, it appears that tumor cell-derived angiopoietin-1 is an absolute requirement for normalization, and that therapy-induced activation of matrix metalloproteinases (MMPs) drives basement membrane degradation leading to the normalization of basement membrane structure (Winkler et al. 2004). Third, the precise effect of anti-VEGF related normalization on tumor growth is still controversial. In many studies, therapy induces a tumor growth delay, but this may well relate to vascular pruning and regression rather than normalization (Kim et al. 1993). Others have shown an increase in the rate of tumor growth accompanying normalization (Stockmann et al. 2008). This could be caused by the improved availability of oxygen and nutrients, but the vast majority of studies revealing improved tumor perfusion and oxygenation after VEGF inhibition have not replicated this finding. Differences could relate to variations in oxygen and glucose consumption rates of different tumors (Gullino 1982).

\section{The Angiopoietin-Tie2 Axis}

The angiopoietin-Tie2 pathway is perhaps the second most important EC-specific pathway regulating both healthy and tumor-associated angiogenesis (Suri et al. 1996; Huang et al. 2010). Angiopoietin-1 (Ang-1, produced primarily by PVCs), and Ang-2, produced primarily by ECs, serve as ligands for the EC Tie-2 receptor. Although their precise actions are complex and context-dependent, Ang- 1 is generally considered a Tie- 2 agonist which promotes vessel maturity and stability and reduces leakiness (Thurston et al. 1999, 2000; Augustin et al. 2009) and Ang-2 serves as a competitive 
antagonist for Tie-2, enhancing tumor angiogenesis and destabilizing blood vessels (Chae et al. 2010).

In keeping with these actions, pharmacological blockade of Ang-2 (but not Ang-1) is able to normalize the tumor vessel phenotype, improving vascular PVC coverage and tightening EC junctions (Falcon et al. 2009). Similarly, wild-type tumors grown in Ang $2^{-/}$mice show an increase in PVC coverage, a reduction in vessel diameter, and a delayed early phase of tumor growth (Nasarre et al. 2009). Ang-2 inhibition operates not only through preventing Ang-2/Tie-2 interaction on ECs, but might also interfere with the proangiogenic activities of Tie-2 expressing monocytes (TEMs) (Coffelt et al. 2010; Mazzieri et al. 2011).

Recently, a dual pharmacological inhibitor of VEGF and the angiopoietins (named the "double antiangiogenic protein," DAAP) (Koh et al. 2010) was shown to inhibit the growth of several murine tumors and, in the case of implanted ovarian carcinoma, resulted in a normalization of vessels. This is likely to be the first of many studies examining the strategy of inhibiting multiple proangiogenic factors to attain a greater degree of vessel normalization.

\section{Placental Growth Factor}

Placental growth factor (PlGF) is another member of the VEGF family that has recently been implicated in tumor angiogenesis and as a regulator of the abnormal tumor vessel phenotype. PlGF is not significantly expressed by normal tissues, but is found abundantly in various tumors (Fischer et al. 2007), and plays an important role in tumors through stimulation of EC growth, mobilization of bone marrow cells, and recruitment of macrophages (Carmeliet et al. 2001) through its binding to VEGFR1 and its coreceptors NRP1 and 2.

Pharmacological PlGF blockade has yielded conflicting results, with some reports demonstrating a profound effect on tumor growth accompanied by angiogenesis inhibition, vessel maturation, resolution of hypoxia, and improved efficacy of chemotherapy (Fischer et al. 2007; Van de Veire et al. 2010), and others demonstrating limited effects on tumor growth (Bais et al. 2010). Recent reports using PlGF ${ }^{-/-}$ mice and si-RNA silencing of PlGF in established tumors suggest that PlGF inhibition can indeed improve vessel structure and induce a tumor growth delay (Van de Veire et al. 2010). The histidine-rich glycoprotein (HRG), through its down-regulation of PlGF, may mediate this process, inducing vessel normalization and also modifications in tumor-associated macrophages from a protumor (M2) to antitumor (M1) phenotype (Huang et al. 2011; Rolny et al. 2011).

\section{Oxygen Sensors}

Given the critical interplay between tumor hypoxia and angiogenesis, modulation of tumor-oxygen sensing has also proven an effective strategy to normalize tumor vessels. First, and not surprisingly, down-regulating tumor HIF- $1 \alpha$ expression inhibits tumor angiogenesis and might improve the efficacy of chemotherapy (Liu et al. 2008). In addition, the EC oxygen sensor PHD2 also plays an important role in generating the abnormal tumor vessel phenotype (Mazzone et al. 2009). Cells in $P H D 2^{+/-}$ mice, by expressing PHD2 at half normal levels, behave as if they sense lower oxygen tensions and as such are preadapted to hypoxia. Syngeneic tumors grown in these mice have normalized vessels, with tight EC junctions (because of a HIF- $2 \alpha$-induced increase in VE-Cadherin expression), a mature PVC phenotype, reduced hypoxia, and less leakiness. These effects are also seen in mice with an EC-specific single allele deletion of PHD2, suggesting that hypoxia (and hence PHD2 inhibition) drives ECs toward a normalized phenotype (as opposed to the effects of hypoxia on tumor cells which promotes VEGF expression and an abnormal vessel phenotype) (Mazzone et al. 2009).

The PHD2 studies also show another important consequence of normalized vessels: Tightened EC junctions in $\mathrm{PHD}^{-/-}$mice lead to a reduction in shedding of primary tumor cells into the circulation, with a consequent decrease in the numbers of circulating tumor cells and metastasis formation (in the 
S. Goel et al.

absence of any effect on primary tumor growth) (Mazzone et al. 2009). Although exciting and of potential clinical relevance, it should be noted that no pharmacologic intervention geared toward normalizing vessels has been able to achieve this goal.

\section{Perivascular Cell Targets}

A number of molecules regulate PVC recruitment to vessels including Ang-1, PDGFR $\beta$, transforming growth factor (TGF)- $\beta$, and sphingosine-1-phosphate (Jain 2003). Already discussed in this article are the importance of Ang- 1 and PDGFR $\beta$ signaling in maintaining normalized vessels. More recently, the regulator of G-protein signaling 5 (Rgs5), a molecule involved in PVC differentiation and a specific marker of PVCs, has been implicated as a key mediator of vascular normalization (Hamzah et al. 2008). Although the function of Rgs5 is poorly understood, tumors growing in Rgs $5^{-/}$mice have a normalized vasculature, showing reduced vessel diameter and structural irregularity, improved oxygenation, and less vessel permeability. Moreover, adoptive transfer of activated immune cells into tumors of $\mathrm{Rgs}^{-/-}$ mice yields increased antitumor $\mathrm{T}$ lymphocyte trafficking and a significant improvement in mouse survival (Hamzah et al. 2008).

\section{Other Angiogenic Molecules}

A number of other critical molecules involved directly in tumor angiogenesis are also contributors to the abnormal vessel phenotype in solid tumors. These include the EC-specific integrins (Friedlander et al. 1995; Kurozumi et al. 2007; Skuli et al. 2009; Desgrosellier and Cheresh 2010; Primo et al. 2010), semaphorins (Bielenberg et al. 2006; Maione et al. 2009), members of the nitric oxide synthase family (Kashiwagi et al. 2005, 2008; Yu et al. 2005), TGF- $\beta$ (Liu et al., submitted for publication), and interferon- $\beta$ (Dickson et al. 2007a,c; Taylor et al. 2008). In keeping with the notion that it is the balance between pro- and antiangiogenic stimuli that moderates the equilibrium between normal and abnormal vessels, modulation of the activity of these molecules is able to normalize tumor vessels structurally and/or functionally in a variety of tumor models preclinically.

\section{Indirect Inhibitors of Angiogenesis}

Unlike the strategies described above, which have direct effects on tumor angiogenesis, a number of drugs affect tumor vessels indirectly. These "indirect" antiangiogenics often inhibit pathways that drive tumor cell proliferation which are coincidentally upstream of pro- or antiangiogenic molecules (Vogelstein and Kinzler 2004). Examples include inhibitors of tumor cell oncogenes, endocrine therapies for sex hormone-dependent tumors, and metronomic chemotherapy.

It is well known that oncogenic activation not only drives tumor cell division but often has multiple other downstream effects including promotion of sustained angiogenesis (Hanahan and Weinberg 2000), either through up-regulation of factors such as VEGF or downregulation of antiangiogenic molecules such as thrombospondin. As a consequence, inhibitors of oncogene activity can indirectly normalize tumor vessels, potentially enhancing not only the action of chemotherapy and radiotherapy, but also their own antitumor cell activity. Investigators have reported various aspects of normalization in response to inhibition of several oncogenes including HER-2 (Izumi et al. 2002), the PI3K-AKT-mTOR axis (Pore et al. 2006a; Schnell et al. 2008; Xue et al. 2008; Qayum et al. 2009), Ras (Cohen-Jonathan et al. 2001; Delmas et al. 2003; Qayum et al. 2009), and the epidermal growth factor receptor (EGFR) (Cerniglia et al. 2009; Qayum et al. 2009; Johns et al. 2010). In the case of HER-2, we have shown that treatment of leptomeningeal HER-2 positive breast cancer with trastuzumab (a monoclonal antibody directed against HER-2) not only inhibits tumor cell proliferation, but also normalizes vessels. These changes occur because HER-2 inhibition modifies the expression of five angiogenesis-related molecules, tipping the pro- versus antiangiogenic balance toward equilibrium (Izumi et al. 2002). 
Results of EGFR inhibition (initially designed to target oncogenic EGFR mutations in diseases such as nonsmall cell lung cancer) have also provided interesting results. EGFR inhibitors such as gefitinib and erlotinib normalize tumor vessel structure and function in several mouse models of solid tumors (Cerniglia et al. 2009; Qayum et al. 2009) and synergize with chemotherapy and/or radiotherapy to maximize tumor control. Importantly, these studies (and others pertaining to oncogene inhibitors) report normalization of longer duration than that observed with anti-VEGF therapy (Qayum et al. 2009), potentially relating to specific suppression of oncogene-driven, excessive VEGF within a tumor rather than total VEGF suppression from anti-VEGF therapy, which ultimately causes vascular regression.

Depriving hormone-dependent tumors of the sex hormones on which they depend represents another mode of indirect antiangiogenic therapy that can normalize vessels. We have shown that castration of mice bearing the androgen-dependent Shionogi carcinoma indirectly reduces tumoral VEGF expression, in turn inducing EC apoptosis, normalizing vessels structurally and functionally, and improving tumor oxygenation (Jain et al. 1998; HansenAlgenstaedt et al. 2000).

A third important method of indirect normalization is "metronomic chemotherapy," a treatment schedule where traditional cytotoxic drugs are given in low doses on a continuous schedule, the goal being to kill tumor ECs (Browder et al. 2000; Kerbel and Kamen 2004) and hence yield an antiangiogenic effect. It seems that at least part of the benefit from metronomic therapy may relate to vessel normalization. ECs exposed to low dose chemotherapy in vitro up-regulate expression of the antiangiogenic thrombospondin-1 (Bocci et al. 2003). As such, metronomic therapy may help to restore the equilibrium between pro- and antiangiogenic factors within tumors. As further support for this notion, metronomic gemcitabine has been shown to reduce vessel density and improve tumor oxygenation in pancreatic cancer xenografts, when compared to gemcitabine given on a conventional schedule (Cham et al. 2010).
This normalization correlated with reductions in the levels of several proangiogenic factors.

\section{Clinical Evidence for Vascular Normalization}

Given the growing body of preclinical evidence suggesting vascular normalization as a potential mechanism of benefit from antiangiogenic therapy, we proceeded to investigate whether similar phenomena occur in human patients (Table 3). Such translational studies are fraught with complexity, requiring adequate numbers of patients who must undergo invasive and noninvasive investigations (often including serial tumor biopsies). Despite these challenges, a number of completed studies have now provided evidence for features of vascular normalization in clinical subjects, in particular disease settings.

The first study was a Phase $1 / 2$ trial in a series of 32 patients with locally advanced rectal carcinoma (Fig. 2) (Willett et al. 2004, 2005, 2009). A single dose of bevacizumab monotherapy normalized tumor vessels within 12 days: (1) after bevacizumab, tumors appeared more pale and less hyperemic, accompanied by a $40 \%$ reduction in tumor blood flow on CT scan and a histological drop in vessel density; (2) tumor IFP fell by > 50\%; (3) vessel PVC coverage increased. Importantly, despite the reduction in vessel density and blood flow, uptake of the radionuclide 18-fluordeoxyglucose on PET scanning did not fall, suggesting that remaining vessels had improved functionality (Willett et al. 2004). More crucially, the pretreatment level of sVEGFR1, a marker of vascular normalization, correlated with treatment outcome and toxicity (Duda et al. 2010).

A second study examined the effects of cediranib in 31 patients with recurrent GBM (Batchelor et al. 2007, 2010; Sorensen et al. 2009). Because serial tissue biopsies cannot be obtained from recurrent GBM patients, advanced "vascular" MRI was used to assess changes in vessel structure and function. Consistent with preclinical models, cediranib induced a rapid reduction in tumor vessel size vessel permeability. This reduction in permeability led to an attenuation of tumor-associated edema and hence the need for corticosteroid therapy. We developed a 
S. Goel et al.

Table 3. Clinical studies demonstrating evidence of vascular normalization in human tumors

\begin{tabular}{|c|c|c|c|c|}
\hline Tumor type & $\begin{array}{l}\text { Antiangiogenic } \\
\text { therapy }\end{array}$ & $\begin{array}{l}\text { Changes in } \\
\text { vessel structure }\end{array}$ & $\begin{array}{l}\text { Changes in vessel } \\
\text { function }\end{array}$ & Clinical observations \\
\hline \multicolumn{5}{|l|}{ Primary tumors } \\
\hline $\begin{array}{l}\text { Rectal carcinoma } \\
\qquad(n=32)\end{array}$ & Bevacizumab & $\begin{array}{l}\downarrow \text { Vessel density, } \\
\uparrow \text { PVC } \\
\text { coverage }\end{array}$ & $\begin{array}{l}\downarrow \text { Tumor blood flow, } \\
\downarrow \text { IFP, improved } \\
\text { delivery of FDG } \\
\text { per vessel }\end{array}$ & $\begin{array}{l}\text { Tumors became pale } \\
\text { (Willett et al. 2004, 2009) }\end{array}$ \\
\hline $\begin{array}{l}\text { Glioblastoma } \\
\quad(n=31)\end{array}$ & Cediranib & $\downarrow$ Vessel size & $\downarrow$ Permeability & $\begin{array}{l}\downarrow \text { tumor-associated edema, } \\
\text { reduced patient need for } \\
\text { corticosteroids (Batchelor } \\
\text { et al. 2007, 2010) }\end{array}$ \\
\hline $\begin{array}{l}\text { High grade glioma } \\
\qquad(n=5)\end{array}$ & Bevacizumab & $\begin{array}{l}\downarrow \text { Vascular } \\
\text { arcades and } \\
\text { glomeruloid } \\
\text { vessels }\end{array}$ & & Fischer et al. 2008 \\
\hline $\begin{array}{l}\text { Prostate } \\
\qquad \text { carcinoma } \\
\quad(n=10)\end{array}$ & $\begin{array}{l}\text { Androgen } \\
\text { ablation }\end{array}$ & $\begin{array}{l}\text { Pruning of } \\
\text { immature } \\
\text { vessels, } \uparrow \text { PVC } \\
\text { coverage }\end{array}$ & & Benjamin et al. 1999 \\
\hline \multicolumn{5}{|l|}{ Metastatic disease } \\
\hline $\begin{array}{l}\text { HER } 2+\text { breast } \\
\text { cancer brain } \\
\text { metastases } \\
(n=22)\end{array}$ & $\begin{array}{l}\text { Lapatinib } \\
\quad \text { (indirect } \\
\text { antiangiogenic) }\end{array}$ & $\begin{array}{l}\downarrow \text { Vessel } \\
\quad \text { tortuosity }\end{array}$ & & Bullitt et al. 2007 \\
\hline
\end{tabular}

mathematical index of vascular normalization (comprising various indirect markers of normalization) and found this to be a strong predictor of individual patient outcomes (Sorensen et al. 2009). In addition to these findings, studies reporting results of serial GBM biopsy and autopsy specimens before and after anti-VEGF therapy have suggested a pattern of structurally more normal vessels after therapy (Fischer et al. 2008; di Tomaso et al. 2011).

\section{VASCULAR ABNORMALITIES AND THERAPEUTIC NORMALIZATION IN NONMALIGNANT DISEASES}

The normalization hypothesis was first supported in the context of the solid tumor vasculature. Recently, however, an explosion in angiogenesis research has revealed that similar vascular abnormalities are seen in a variety of nonmalignant diseases. These observations, coupled with a heightened understanding of the deleterious effects of an abnormal vascula- ture, have led to a number of studies exploring the benefits of antiangiogenic therapy-induced vascular normalization in a variety of common and rare benign diseases.

\section{Benign Tumors}

Although lacking metastatic potential, benign tumors still depend on angiogenesis to fuel their persistent growth, and the balance between pro- and antiangiogenic factors plays an important role in their progression. Awell-characterized example is the vestibular schwannoma (acoustic neuroma), a benign hyperproliferation of the Schwann cells that line peripheral nerves. Neurofibromatosis 2, a rare genetic disease defined by a defect in a single allele of the Nf2 gene (and hence loss of its product, the tumor suppressor merlin) often presents with bilateral acoustic neuromata, which compress the vestibular nerve causing deafness and other complications relating to their expansion in the cerebellopontine angle (Lu-Emerson and Plotkin 2009). 


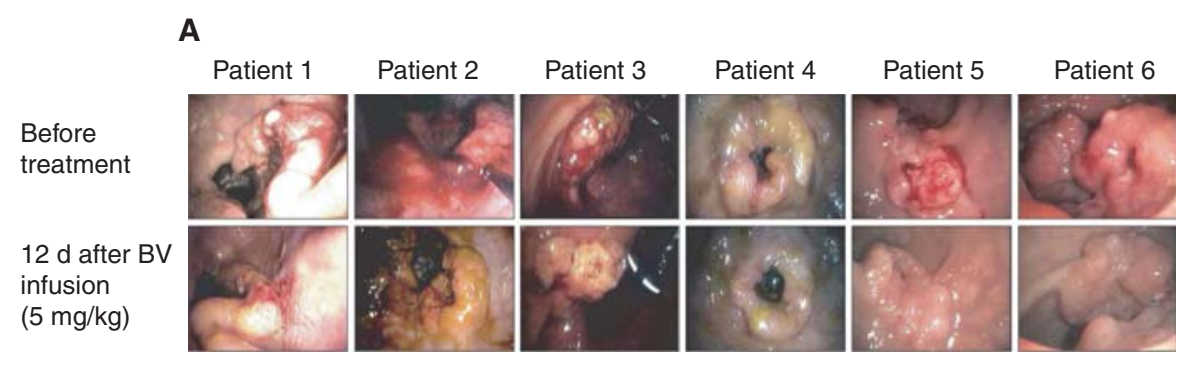

B

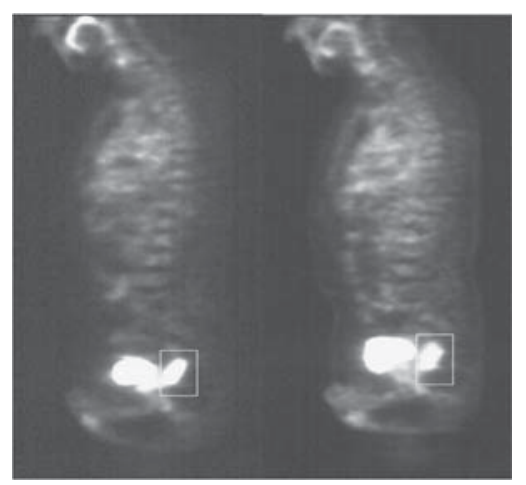

C

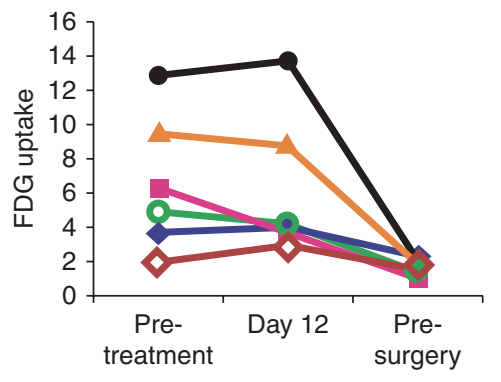

Figure 2. Direct effects of antiangiogenic therapy in human patients with locally advanced adenocarcinoma of the rectum. (A) Six patients were treated with locally advanced rectal cancer underwent sigmoidoscopy before (upper panels) and 12 days after (lower panels) a single dose of bevacizumab (antihuman VEGF antibody). Tumors appear notably less hyperaemic after treatment, associated with a quantifiable decrease in tumor blood flow. (B) Positron emission tomography (PET) scanning using fluoro-deoxyglucose (FDG). Despite the reduction in tumor blood flow, the amount of extravasated FDG is similar before (left panel) and after (right panel) bevacizumab treatment, implying improved functionality of surviving vessels. $(C)$ Graphical representation of FDG uptake on PET scanning for six patients. Again, there is no difference in tumor uptake of FDG between pretreatment values and those 12 days after a single dose of bevacizumab. (Figure adapted from Willett et al. 2004; reprinted, with permission, from Nature Publishing Group (C) 2004.)

Vestibular schwannomas are known to express VEGF and VEGFRs, and the VEGF level within these tumors correlates with their growth rate (Brieger et al. 2003; CayeThomasen et al. 2003, 2005; Plotkin et al. 2009). Interestingly, the mechanism of heightened VEGF activity in these tumors is not hypoxia-driven VEGF overexpression, but rather a loss of factors that attenuate VEGF function. In detail, merlin deficiency in schwannoma cells is associated with a concomitant down-regulation of SEMA 3D, SEMA 3F, and SEMA 3G (Wong et al. 2010). These semaphorins normally act via neuropilin receptors as negative regulators of VEGF activity, and loss of their antiangiogenic influence drives robust angiogenesis in schwannomas.

In preclinical studies, we have treated orthotopic schwannomas derived from both human schwannoma cells and murine NF2 null cells with anti-VEGF agents (Wong et al. 2010). Therapy reproduced many aspects of vascular normalization, including a prompt reduction in tumor vessel permeability, and a reduction in vessel surface area seen by day 6 of treatment. As anti-VEGF therapy tipped the balance between pro- and antiangiogenic factors toward normal, structural features of normalization including an increase in PVC coverage were also observed. In keeping with the known 
S. Goel et al.

correlation between VEGF activity and growth rate in these tumors, anti-VEGF therapy inhibited tumor growth, an effect mediated primarily through an antiangiogenic effect (Wong et al. 2010). As proof of concept, we have also shown that reintroduction of SEMA3F into NF2 null cells reduces the growth of implanted tumors, which show a reduction in vessel density and improved PVC coverage (HK Wong, A Shimizu, ND Kirkpatrick, et al., unpubl. data). Micebearing $N F 2^{-/-}$(SEMA3F) tumors in the brain also have prolonged survival compared with those bearing $\mathrm{NF}^{-/-}$tumors without SEMA3F.

These features have been emphasized through the results of a clinical trial in NF2 patients (Plotkin et al. 2009). In this study, semaphorin down-regulation was observed in patient acoustic neuroma specimens, and treatment with bevacizumab resulted in a $60 \%$ reduction in tumor growth, and a corresponding improvement in hearing acuity. Importantly, the intratumoral apparent diffusion coefficient on MRI (ADC, a measure of the magnitude of water diffusion) correlated with the degree of tumor shrinkage, suggesting that patients with excess edema are most likely to benefit from bevacizumab treatment. These clinical findings are supported by the preclinical data, and confirm the benefit of vessel normalization in this benign tumor. Delaying tumor growth in this disease is likely to delay the need for more aggressive therapies such as surgery to prevent tumor-associated morbidity.

\section{Age-Related Macular Degeneration}

Perhaps the most successful application of antiangiogenic therapy has been in the treatment of age-related macular degeneration (ARMD), the leading cause of blindness in the United States (Bressler 2009a,b). "Wet" ARMD, the less common but more disabling form of the disease, has as its hallmark excessive choroidal angiogenesis, seen beneath the retinal pigment epithelium (RPE) and also between the RPE and overlying retina. Several proangiogenic factors serve as players in the retinal microenvironment (including FGF, PDGF, and PlGF), but VEGF overexpression by RPE cells (caused by focal hypoxia and abnormal thickening of Bruch's membrane) is the most important (Bressler 2009b; Rajappa et al. 2010). VEGF abundance results in a retinal vasculature resembling that of solid tumors, characterized by focal macular edema and retinal hemorrhage.

Traditional therapy for wet ARMD involves laser photocoagulation of proliferative vessels, and pharmacologic therapy has proved an elusive goal until recently. Given the crucial role for VEGF in this disease, two anti-VEGF therapeutics have been developed as treatment of wet ARMD with great success leading to their approval for clinical use by the U.S. FDA. The two main agents are ranibizumab (a humanized monoclonal antibody fragment derived from the same murine antibody as bevacizumab) and pegaptanib (a pegylated aptamer that binds to VEGF). Both are administered by serial intravitreal injections. In the case of pegaptanib, preclinical work shows features of vascular normalization in response to treatment including a reduction in microvascular leakage, leukocyte adhesion, and choroidal neovascularization (Eyetech Study Group 2002; Ishida et al. 2003). Clinical observations also confirm a reduction in vascular leakage (as detected by fluorescein angiography) after treatment with anti-VEGF agents (Bressler 2009a). In turn, this normalized vessel phenotype dramatically alters the retinal microenvironment and has led to impressive clinical results (Gragoudas et al. 2004; Rosenfeld et al. 2006; Ferrara 2010), including improved visual acuity lasting for up to 24 mo after commencement of therapy.

\section{Cutaneous Psoriasis}

Psoriasis is a chronic inflammatory skin disease characterized by hyperproliferation of keratinocytes and angiogenesis, and is another nonmalignant disease in which abnormal angiogenesis is critical to disease progression. Current models suggest that angiogenesis is required for the induction of psoriatic pathology and maintains the immune and inflammatory processes that drive psoriasis (Heidenreich et al. 2009).

Cutaneous psoriasis starts with angiogenesis in the superficial dermal microvasculature. 
Dermal papillary capillaries increase in tortuosity, diameter and permeability, and show prominent elongation. Psoriatic plaques show characteristic features of venous capillaries, as opposed to normal skin in which capillary loops show an arterial phenotype (Braverman and Yen 1977). Besides these morphological changes, papillary dermal microvessels in psoriatic lesions show increased expression of inflammation-associated adhesion molecules such as E-selectin, Intercellular adhesion molecule-1 (ICAM-1) and vascular cell-adhesion molecule-1 (VCAM-1) (Das et al. 1994). These molecules allow adhesion of leukocytes to the endothelium and the establishment of an inflammatory response. Endothelial cells of psoriasis plaques also show enhanced proliferation (Creamer et al. 1997).

Underlying psoriatic angiogenesis, several proangiogenic factors including tumor necrosis factor- $\alpha$ (TNF-a), VEGF, HIFs, Interleukin (IL)-8, and angiopoietins, are all enriched in psoriatic skin (Heidenreich et al. 2009). As abnormal angiogenesis is considered to be the key to the initiation and progression of psoriasis, several antiangiogenic therapies have been developed to treat psoriasis. These agents either interfere either directly or indirectly with pathways regulating endothelial cell physiology, or directly targeting angiogenesis. Through attenuating proangiogenic stimuli, these agents act to reduce vascular abnormalities seen in psoriatic plaques and hence moderate disease progression.

The effects of VEGF blockade have been reported using genetic murine models of psoriasis. After therapy, a reduction in vessel density and diameter was observed, corresponding to a reduction in severity of skin lesions (Schonthaler et al. 2009). Clinical case reports have also suggested improvement in skin lesions after treatment with anti-VEGFR TKIs (Keshtgarpour and Dudek 2007; Fournier and Tisman 2010; Narayanan et al. 2010). More recently, nonviral somatic delivery of the recombinant disintegrin domain (RDD) of metargidin, which interferes with the VEGF pathway and angiogenesis, was shown to lower cutaneous blood flow in psoriasis-affected mice and reduce disease severity (Zibert et al. 2010). Given these data, prospective and controlled clinical trials are needed to evaluate the efficacy of these and other antiangiogenic therapies to determine the extent to which vessel normalization underpins the observed clinical benefit.

\section{Hereditary Hemorrhagic Telangiectasia}

Hereditary hemorrhagic telangiectasia (HHT), also known as Osler-Weber-Rendu syndrome, is a rare autosomal dominant genetic disease characterized by excessive and abnormal blood vessel formation. Patients with HHT harbor large numbers of vascular telangiectasias, most prominent on mucous membranes and skin, and as arteriovenous malformations (AVMs) in the brain, lung, and liver. These malformations comprise dilated, thin-walled networks of dysplastic capillaries that are inherently fragile and prone to bleeding, giving rise to symptoms such as epistaxis, excessive bruising, and potentially life-threatening visceral and intracranial hemorrhage.

Small case series have suggested a beneficial role for antiangiogenic therapy in HHT. Bevacizumab, for example, has been shown to dramatically reduce the frequency of epistaxis and blood transfusion requirements (Flieger et al. 2006; Bose et al. 2009). More recently, a translational study shed light on the mechanism of action of antiangigogenic therapy in HHT. Using a murine genetic model of HHT, Lebrin and colleagues found that the antiangiogenic agent thalidomide increased vessel maturity in telangiectatic regions (as evidenced by increased PVC coverage), hence normalizing vessels and attenuating vessel wall defects (Lebrin et al. 2010). This benefit is at least in part mediated by PDGF-B mediated recruitment of PVCs to ECs. Moreover, the same group found that treating HHT patients with thalidomide normalized vessels in the nasal mucosa and reduced epistaxis significantly.

\section{Atherosclerotic Plaques}

Alongside cancer, atherosclerosis represents a major cause of mortality worldwide. Although the role for angiogenesis in the progression of 
S. Goel et al.

atherosclerotic plaque development is a young and relatively unexplored area, evidence does suggest that new vessel formation in the coronary plaque vasa vasorum is an important contributor to disease progression and plaque complications (Jeziorska and Woolley 1999; Kolodgie et al. 2003; Virmani et al. 2005; Jain et al. 2007). Indeed, hypoxia within plaques drives angiogenesis and an abnormal vasculature. The plaque microenvironment also contains high levels of eNOS and TNF- $\alpha$. As a result, intra-plaque hemorrhage can occur (particularly in noncalcified plaques, which have the highest vessel density and are more prone to rupture), accelerating plaque progression and rupture, and leading to myocardial infarction (Gossl et al. 2010).

Preclinical studies in genetic models of atherosclerosis have examined the effects of angiogenesis inhibition on plaque biology. For example, the angiogenesis inhibitors endostatin and TNP-470 have been shown to not only reduce new vessel formation within plaques, but also slow plaque growth (Moulton et al. 1999). Although it might be possible that judicious use of antiangiogenic therapy could be used to normalize plaque vessels, potentially minimizing the risk of plaque hemorrhage and the attendant consequences, research is currently limited by the lack of suitable animal models to test appropriate agents, doses, and schedules.

\section{NORMALIZATION OF THE LYMPHATIC VASCULATURE: AN EMERGING CONCEPT IN VASCULAR NORMALIZATION}

Although normalization of tumor vessels is a concept largely pertaining to blood vessels, recent evidence suggests marked abnormalities in the function of solid tumor lymphatics. From the very early stages of tumor development, the lymphatic microvasculature becomes compressed and dysfunctional (Hagendoorn et al. 2006). The impaired function relates partly to compression, but also to valvular damage, impaired contractile activity, and occlusion by tumor cells (Padera et al. 2004). A good example is carcinoma of the ovary. Both mice and patients with disseminated ovarian cancer develop gross abdominal ascites, caused in part by impaired drainage of peritoneal fluid by regional lymphatics. We have recently found that diaphragmatic lymphatics in ovarian cancer-bearing mice have structural abnormalities not dissimilar from those found in tumor blood vessels, namely increased vessel density, diameter, and tortuosity (Liao et al. 2011). They also show impaired function with loss of valves and sluggish clearance of peritoneal fluid. Interestingly, when we inhibited the function of TGF- $\beta$, either pharmacologically or genetically, we observed normalization of lymphatic structure and function (Liao et al. 2011). TGF- $\beta$ has known effects on both tumor cell biology and lymphangiogenesis, and the improved lymphatic function in such models may relate partly to relief of compression through a reduction in tumor burden. Such findings open avenues for future research into normalization of the lymphatic phenotype in tumors and other diseases characterized by lymphatic dysfunction.

\section{SUMMARY}

Research over several decades has clearly shown marked abnormalities in the tumor microvasculature, which have profound consequences for tumor growth, metastasis, and response to therapy. Although initial preclinical studies showed that anti-VEGF therapy is able to kill tumor vessels and destroy tumor vessels, the results of bevacizumab monotherapy in patients with solid tumors were overwhelmingly disappointing. Despite this, anti-VEGF treatments have been able to improve the efficacy of systemic chemotherapy, suggesting that they augment chemotherapy benefit in some way. The vascular normalization hypothesis helps to explain these findings. By restoring the balance between pro- and antiangiogenic factors in the tumor microenvironment, antiangiogenic therapy is able to restore a more normal tumor vasculature, capable of delivering cytotoxics more efficiently into tumors and enhancing the effects of radiotherapy. In recent years, a plethora of preclinical studies have shed 
light on the molecular regulators of this phenotypic switch.

Further understanding of the normalization process is required before it can be most effectively exploited in the clinical setting, which will be difficult given the great heterogeneity in tumor vessels within a single patient and between patients. First, as discussed above, the impact of vascular normalization on primary tumor growth requires further study. Second, further work is needed to resolve the controversy over whether antiangiogenic therapy through normalization serves to decrease the rate of solid tumor metastasis or through excessive vascular pruning serves to increase metastasis. Third, mechanisms of resistance to the normalization process should be explored, with the ultimate goal of developing pharmacologic therapies that can induce sustained vascular normalization in tumors. Fourth, more attention must be given to the wide range of benign diseases characterized by abnormal angiogenesis - a largely unexplored area potentially offering improved outcomes for millions of patients worldwide. Finally, biomarkers for vascular normalization are sorely needed to use this concept optimally in the clinical setting (Jain et al. 2009).

\section{ACKNOWLEDGMENTS}

S.G. is supported by the Australian-American Fulbright Commission and an American Society for Clinical Oncology Young Investigator Award. The research of R.K.J. is supported by the U.S. National Institutes of Health (NIH) grants P01-CA80124, R01-CA85140, R01-CA115767, and R01-CA126642, Federal Share/NCI Proton Beam Program Income, National Foundation for Cancer Research, and Department of Defense Breast Cancer Research Innovator Award (W81XWH-10-1-0016).

\section{CONFLICTS OF INTEREST}

R.K.J. has served in a consultant or advisory role to Astellas, AstraZeneca, Dyax, Genzyme, Noxxon Pharma, Regeneron, and SynDevRx, has equity in SynDevRx, has received honoraria from Genzyme, and has received research funding from AstraZeneca, Dyax, MedImmune, and Roche.

\section{REFERENCES}

Abramsson A, Lindblom P, Betsholtz C. 2003. Endothelial and nonendothelial sources of PDGF-B regulate pericyte recruitment and influence vascular pattern formation in tumors. J Clin Invest 112: 1142-1151.

Ader I, Delmas C, Bonnet J, Rochaix P, Favre G, Toulas C, Cohen-Jonathan-Moyal E. 2003. Inhibition of Rho pathways induces radiosensitization and oxygenation in human glioblastoma xenografts. Oncogene 22: $8861-$ 8869.

Algire GH, Chalkley HW. 1945. Vascular reactions of normal and malignant tissues in vivo. I. Vascular reactions of mice to wounds and to normal and neoplastic transplants. J Natl Cancer Inst 6: 73-85.

Ansiaux R, Baudelet C, Jordan BF, Beghein N, Sonveaux P De Wever J, Martinive P, Gregoire V, Feron O, Gallez B. 2005. Thalidomide radiosensitizes tumors through early changes in the tumor microenvironment. Clin Cancer Res 11: $743-750$.

Ansiaux R, Baudelet C, Jordan BF, Crokart N, Martinive P, DeWever J, Gregoire V, Feron O, Gallez B. 2006. Mechanism of reoxygenation after antiangiogenic therapy using SU5416 and its importance for guiding combined antitumor therapy. Cancer Res 66: 9698-9704.

Augustin HG, Koh GY, Thurston G, Alitalo K. 2009. Control of vascular morphogenesis and homeostasis through the angiopoietin-Tie system. Nat Rev Mol Cell Biol 10: $165-177$.

Bais C, Wu X, Yao J, Yang S, Crawford Y, McCutcheon K, Tan C, Kolumam G, Vernes JM, Eastham-Anderson J, et al. 2010. PlGF blockade does not inhibit angiogenesis during primary tumor growth. Cell 141: 166-177.

Baish JW, Stylianopoulos T, Lanning RM, Kamoun WS, Fukumura D, Munn LL, Jain RK. 2011. Scaling rules for diffusive drug delivery in tumor and normal tissues. Proc Natl Acad Sci 108: 1799-1803.

Batchelor TT, Sorensen AG, di Tomaso E, Zhang WT, Duda DG, Cohen KS, Kozak KR, Cahill DP, Chen PJ, Zhu M, et al. 2007. AZD2171, a pan-VEGF receptor tyrosine kinase inhibitor, normalizes tumor vasculature and alleviates edema in glioblastoma patients [see comment]. Cancer Cell 11: 83-95.

Batchelor TT, Duda DG, di Tomaso E, Ancukiewicz M, Plotkin SR, Gerstner E, Eichler AF, Drappatz J, Hochberg FH, Benner T, et al. 2010. Phase II study of cediranib, an oral pan-vascular endothelial growth factor receptor tyrosine kinase inhibitor, in patients with recurrent glioblastoma. J Clin Oncol 28: 2817-2823.

Batra S, Matsumoto S, Hyodo F, Mitchell J, Krishna MC. 2009. MRI assessment of angiogenesis inhibitor Sunitinib's influence on tumor oxygenation to identify an optimal chemoradiotherapeutic window. Int J Radiat Oncol Biol Phys 75: S43.

Benjamin LE, Golijanin D, Itin A, Pode D, Keshet E. 1999. Selective ablation of immature blood vessels in established human tumors follows vascular endothelial growth factor withdrawal. J Clin Invest 103: 159-165. 
S. Goel et al.

Bernsen HJ, Rijken PF, Peters JP, Bakker JH, Boerman RH, Wesseling P, van der Kogel AJ. 1999. Suramin treatment of human glioma xenografts; effects on tumor vasculature and oxygenation status. J Neurooncol 44: 129-136.

Bhattacharya A, Seshadri M, Oven SD, Toth K, Vaughan MM, Rustum YM. 2008. Tumor vascular maturation and improved drug delivery induced by methylselenocysteine leads to therapeutic synergy with anticancer drugs. Clin Cancer Res 14: 3926-3932.

Bhattacharya A, Toth K, Sen A, Seshadri M, Cao S, Durrani FA, Faber E, Repasky EA, Rustum YM. 2009. Inhibition of colon cancer growth by methylselenocysteine-induced angiogenic chemomodulation is influenced by histologic characteristics of the tumor. Clin Colorectal Cancer 8: $155-162$.

Bielenberg DR, Pettaway CA, Takashima S, Klagsbrun M. 2006. Neuropilins in neoplasms: Expression, regulation, and function. Exp Cell Res 312: 584-593.

Bocci G, Francia G, Man S, Lawler J, Kerbel RS. 2003. Thrombospondin 1, a mediator of the antiangiogenic effects of low-dose metronomic chemotherapy. Proc Natl Acad Sci 100: 12917-12922.

Bose P, Holter JL, Selby GB. 2009. Bevacizumab in hereditary hemorrhagic telangiectasia. $N$ Engl J Med 360: 2143-2144.

Boucher Y, Baxter LT, Jain RK. 1990. Interstitial pressure gradients in tissue-isolated and subcutaneous tumors: Implications for therapy. Cancer Res 50: 4478-4484.

Boucher Y, Kirkwood JM, Opacic D, Desantis M, Jain RK. 1991. Interstitial hypertension in superficial metastatic melanomas in humans. Cancer Res 51: 6691-6694.

Braverman IM, Yen A. 1977. Ultrastructure of the capillary loops in the dermal papillae of psoriasis. J Invest Dermatol 68: $53-60$

Bressler NM. 2009a. Antiangiogenic approaches to agerelated macular degeneration today. Ophthalmology 116: S15-S23.

Bressler SB. 2009b. Introduction: Understanding the role of angiogenesis and antiangiogenic agents in age-related macular degeneration. Ophthalmology 116: S1-S7.

Brieger J, Bedavanija A, Lehr HA, Maurer J, Mann WJ. 2003. Expression of angiogenic growth factors in acoustic neurinoma. Acta Otolaryngol 123: 1040-1045.

Browder T, Butterfield CE, Kraling BM, Shi B, Marshall B, O’Reilly MS, Folkman J. 2000. Antiangiogenic scheduling of chemotherapy improves efficacy against experimental drug-resistant cancer. Cancer Res 60: 1878-1886.

Bullitt E, Lin NU, Smith JK, Zeng D, Winer EP, Carey LA, Lin W, Ewend MG. 2007. Blood vessel morphologic changes depicted with MR angiography during treatment of brain metastases: A feasibility study. Radiology 245: 824-830.

Carmeliet P, Jain RK. 2011. Molecular mechanisms and clinical applications of angiogenesis. Nature 473: 298-307.

Carmeliet P, Moons L, Luttun A, Vincenti V, Compernolle V, De Mol M, Wu Y, Bono F, Devy L, Beck H, et al. 2001. Synergism between vascular endothelial growth factor and placental growth factor contributes to angiogenesis and plasma extravasation in pathological conditions. Nat Med 7: 575-583.

Caye-Thomasen P, Baandrup L, Jacobsen GK, Thomsen J, Stangerup SE. 2003. Immunohistochemical demonstra- tion of vascular endothelial growth factor in vestibular schwannomas correlates to tumor growth rate. Laryngoscope 113: 2129-2134.

Caye-Thomasen P, Werther K, Nalla A, Bog-Hansen TC, Nielsen HJ, Stangerup SE, Thomsen J. 2005. VEGF and VEGF receptor-1 concentration in vestibular schwannoma homogenates correlates to tumor growth rate. Otol Neurotol 26: 98-101.

Cerniglia GJ, Pore N, Tsai JH, Schultz S, Mick R, Choe R, Xing X, Durduran T, Yodh AG, Evans SM, et al. 2009. Epidermal growth factor receptor inhibition modulates the microenvironment by vascular normalization to improve chemotherapy and radiotherapy efficacy. PLoS One 4: e6539.

Chae SS, Kamoun WS, Farrar CT, Kirkpatrick ND, Niemeyer E, de Graaf AM, Sorensen AG, Munn LL, Jain RK, Fukumura D. 2010. Angiopoietin-2 interferes with anti-VEGFR2-induced vessel normalization and survival benefit in mice bearing gliomas. Clin Cancer Res 16: 3618-3627.

Cham KK, Baker JH, Takhar KS, Flexman JA, Wong MQ, Owen DA, Yung A, Kozlowski P, Reinsberg SA, Chu EM, et al. 2010. Metronomic gemcitabine suppresses tumour growth, improves perfusion, and reduces hypoxia in human pancreatic ductal adenocarcinoma. $\mathrm{Br} J$ Cancer 103: 52-60.

Chung AS, Lee J, Ferrara N. 2010. Targeting the tumour vasculature: Insights from physiological angiogenesis. Nat Rev Cancer 10: 505-514.

Coffelt SB, Tal AO, Scholz A, De Palma M, Patel S, Urbich C, Biswas SK, Murdoch C, Plate KH, Reiss Y, et al. 2010. Angiopoietin-2 regulates gene expression in TIE2-expressing monocytes and augments their inherent proangiogenic functions. Cancer Res 70: 5270-5280.

Cohen-Jonathan E, Evans SM, Koch CJ, Muschel RJ, McKenna WG, Wu J, Bernhard EJ. 2001. The farnesyltransferase inhibitor L744,832 reduces hypoxia in tumors expressing activated H-ras. Cancer Res 61: 2289-2293.

Creamer D, Allen MH, Sousa A, Poston R, Barker JN. 1997. Localization of endothelial proliferation and microvascular expansion in active plaque psoriasis. Br J Dermatol 136: $859-865$.

Das PK, de Boer OJ, Visser A, Verhagen CE, Bos JD, Pals ST. 1994. Differential expression of ICAM-1, E-selectin and VCAM- 1 by endothelial cells in psoriasis and contact dermatitis. Acta Derm Venereol Suppl (Stockh) 186: 21-22.

DeClerck K, Elble RC. 2010. The role of hypoxia and acidosis in promoting metastasis and resistance to chemotherapy. Front Biosci 15: 213-225.

Delmas C, End D, Rochaix P, Favre G, Toulas C, CohenJonathan E. 2003. The farnesyltransferase inhibitor R115777 reduces hypoxia and matrix metalloproteinase 2 expression in human glioma xenograft. Clin Cancer Res 9: 6062-6068.

Desgrosellier JS, Cheresh DA. 2010. Integrins in cancer: Biological implications and therapeutic opportunities. Nat Rev Cancer 10: 9-22.

Dickson PV, Hagedorn NL, Hamner JB, Fraga CH, Ng CY, Stewart CF, Davidoff AM. 2007a. Interferon $\beta$-mediated vessel stabilization improves delivery and efficacy of systemically administered topotecan in a murine neuroblastoma model. J Pediat Surg 42: 160-165. 
Dickson PV, Hamner JB, Sims TL, Fraga CH, Ng CY, Rajasekeran S, Hagedorn NL, McCarville MB, Stewart CF, Davidoff AM. 2007b. Bevacizumab-induced transient remodeling of the vasculature in neuroblastoma xenografts results in improved delivery and efficacy of systemically administered chemotherapy. Clin Cancer Res 13: 3942-3950.

Dickson PV, Hamner JB, Streck CJ, Ng CY, McCarville MB, Calabrese C, Gilbertson RJ, Stewart CF, Wilson CM, Gaber MW, et al. 2007c. Continuous delivery of IFN- $\beta$ promotes sustained maturation of intratumoral vasculature. Molec Cancer Res 5: 531-542.

Dings RP, Loren M, Heun H, McNiel E, Griffioen AW, Mayo KH, Griffin RJ. 2007. Scheduling of radiation with angiogenesis inhibitors anginex and Avastin improves therapeutic outcome via vessel normalization. Clin Cancer Res 13: 3395-3402.

Dirkx AE, oude Egbrink MG, Castermans K, van der Schaft DW, Thijssen VL, Dings RP, Kwee L, Mayo KH, Wagstaff J, Bouma-ter Steege JC, et al. 2006. Anti-angiogenesis therapy can overcome endothelial cell anergy and promote leukocyte-endothelium interactions and infiltration in tumors. FASEB J 20: 621-630.

di Tomaso E, London N, Fuja D, Logie J, Tyrrell JA, Kamoun W, Munn LL, Jain RK. 2009. PDGF-C induces maturation of blood vessels in a model of glioblastoma and attenuates the response to anti-VEGF treatment. PLoS ONE 4: e5123.

di Tomaso E, Snuderl M, Kamoun WS, Duda DG, Auluck PK, Andronesi OC, Frosch MP, Wen PY, Plotkin SR, Hedley-Whyte ET, et al. 2011. Glioblastoma recurrence after Cediranib therapy in patients: Lack of "rebound" revascularization as mode of escape. Cancer Res 71: $19-28$.

Duda DG, Willett CG, Ancukiewicz M, di Tomaso E, Shah M, Czito BG, Bentley R, Poleski M, Lauwers GY, Carroll M, et al. 2010. Plasma soluble VEGFR-1 is a potential dual biomarker of response and toxicity for bevacizumab with chemoradiation in locally advanced rectal cancer. Oncologist 15: 577-583.

Dvorak HF. 1986. Tumors: Wounds that do not heal. Similarities between tumor stroma generation and wound healing. N Engl J Med 315: 1650-1659.

Ebos JM, Lee CR, Cruz-Munoz W, Bjarnason GA, Christensen JG, Kerbel RS. 2009. Accelerated metastasis after short-term treatment with a potent inhibitor of tumor angiogenesis. Cancer Cell 15: 232-239.

Eichhorn ME, Strieth S, Luedemann S, Kleespies A, Noth U, Passon A, Brix G, Jauch KW, Bruns CJ, Dellian M. 2008. Contrast enhanced MRI and intravital fluorescence microscopy indicate improved tumor microcirculation in highly vascularized melanomas on short-term antiVEGFR treatment [see comment]. Cancer Biol Ther 7: 1006-1013.

Eyetech Study Group. 2002. Preclinical and phase 1A clinical evaluation of an anti-VEGF pegylated aptamer (EYE001) for the treatment of exudative age-related macular degeneration. Retina 22: 143-152.

Falcon BL, Hashizume H, Koumoutsakos P, Chou J, Bready JV, Coxon A, Oliner JD, McDonald DM. 2009. Contrasting actions of selective inhibitors of angiopoietin- 1 and angiopoietin-2 on the normalization of tumor blood vessels. Am J Pathol 175: 2159-2170.

Ferrara N. 2005. VEGF as a therapeutic target in cancer. Oncology 69 (Suppl 3): 11-16.

Ferrara N. 2010. Vascular endothelial growth factor and age-related macular degeneration: From basic science to therapy. Nat Med 16: 1107-1111.

Fischer C, Jonckx B, Mazzone M, Zacchigna S, Loges S, Pattarini L, Chorianopoulos E, Liesenborghs L, Koch M, De Mol M, et al. 2007. Anti-PlGF inhibits growth of VEGF(R)-inhibitor-resistant tumors without affecting healthy vessels. Cell 131: 463-475.

Fischer I, Cunliffe CH, Bollo RJ, Raza S, Monoky D, Chiriboga L, Parker EC, Golfinos JG, Kelly PJ, Knopp EA, et al. 2008. High-grade glioma before and after treatment with radiation and Avastin: Initial observations [see comment]. Neuro-Oncology 10: 700-708.

Flieger D, Hainke S, Fischbach W. 2006. Dramatic improvement in hereditary hemorrhagic telangiectasia after treatment with the vascular endothelial growth factor (VEGF) antagonist bevacizumab. Ann Hematol 85: 631-632.

Folkman J. 1971. Tumor angiogenesis: therapeutic implications. N Engl J Med 285: 1182-1186.

Fournier C, Tisman G. 2010. Sorafenib-associated remission of psoriasis in hypernephroma: Case report. Dermatol Online J 16: 17.

Friedlander M, Brooks PC, Shaffer RW, Kincaid CM, Varner JA, Cheresh DA. 1995. Definition of two angiogenic pathways by distinct $\alpha \mathrm{v}$ integrins. Science 270: 1500-1502.

Giantonio BJ, Catalano PJ, Meropol NJ, O’Dwyer PJ, Mitchell EP, Alberts SR, Schwartz MA, Benson AB 3rd. 2007. Bevacizumab in combination with oxaliplatin, fluorouracil, and leucovorin (FOLFOX4) for previously treated metastatic colorectal cancer: Results from the Eastern Cooperative Oncology Group Study E3200. J Clin Oncol 25: $1539-1544$.

Goel S, Duda DG, Xu L, Munn LL, Boucher Y, Fukumura D, Jain RK. 2011. Normalization of the vasculature for treatment of cancer and other diseases. Physiol Rev 91: 1071-1121.

Gorski DH, Beckett MA, Jaskowiak NT, Calvin DP, Mauceri HJ, Salloum RM, Seetharam S, Koons A, Hari DM, Kufe DW, et al. 1999. Blockage of the vascular endothelial growth factor stress response increases the antitumor effects of ionizing radiation. Cancer Res 59: 3374-3378.

Gossl M, Versari D, Hildebrandt HA, Bajanowski T, Sangiorgi G, Erbel R, Ritman EL, Lerman LO, Lerman A. 2010. Segmental heterogeneity of vasa vasorum neovascularization in human coronary atherosclerosis. JACC Cardiovasc Imaging 3: 32-40.

Gragoudas ES, Adamis AP, Cunningham ET Jr, Feinsod M, Guyer DR. 2004. Pegaptanib for neovascular age-related macular degeneration. $N$ Engl J Med 351: 2805-2816.

Greenberg JI, Shields DJ, Barillas SG, Acevedo LM, Murphy E, Huang J, Scheppke L, Stockmann C, Johnson RS, Angle N, et al. 2008. A role for VEGF as a negative regulator of pericyte function and vessel maturation. Nature 456: $809-813$.

Griffioen AW, Damen CA, Blijham GH, Groenewegen G. 1996. Tumor angiogenesis is accompanied by a decreased 
S. Goel et al.

inflammatory response of tumor-associated endothelium. Blood 88: 667-673.

Gullino PM. 1982. Vascular normalization. In Biomedical thermology (ed. Gautherie M, Albert E). A.R. Liss, New York.

Hagendoorn J, Tong R, Fukumura D, Lin Q, Lobo J, Padera TP, Xu L, Kucherlapati R, Jain RK. 2006. Onset of abnormal blood and lymphatic vessel function and interstitial hypertension in early stages of carcinogenesis. Cancer Res 66: $3360-3364$.

Hamzah J, Jugold M, Kiessling F, Rigby P, Manzur M, Mart HH, Rabie T, Kaden S, Grone HJ, Hammerling GJ, et al. 2008. Vascular normalization in Rgs5-deficient tumours promotes immune destruction. Nature 453: 410-414.

Hanahan D, Weinberg RA. 2000. The hallmarks of cancer. Cell 100: 57-70.

Hansen-Algenstaedt N, Stoll BR, Padera TP, Dolmans DE Hicklin DJ, Fukumura D, Jain RK. 2000. Tumor oxygenation in hormone-dependent tumors during vascular endothelial growth factor receptor-2 blockade, hormone ablation, and chemotherapy. Cancer Res 60: 4556-4560.

Hashizume H, Baluk P, Morikawa S, McLean JW, Thurston G, Roberge S, Jain RK, McDonald DM. 2000. Openings between defective endothelial cells explain tumor vessel leakiness. Am J Pathol 156: 1363-1380.

Heidenreich R, Rocken M, Ghoreschi K. 2009. Angiogenesis drives psoriasis pathogenesis. Int J Exp Pathol 90: 232-248.

Herbst RS, Sun Y, Eberhardt WE, Germonpre P, Saijo N, Zhou C, Wang J, Li L, Kabbinavar F, Ichinose Y, et al. 2010. Vandetanib plus docetaxel versus docetaxel as second-line treatment for patients with advanced nonsmall-cell lung cancer (ZODIAC): A double-blind, randomised, phase 3 trial. Lancet Oncol 11: 619-626.

Hobbs SK, Monsky WL, Yuan F, Roberts WG, Griffith L, Torchilin VP, Jain RK. 1998. Regulation of transport pathways in tumor vessels: Role of tumor type and microenvironment. Proc Natl Acad Sci 95: 4607-4612.

Huang X, Wong MK, Yi H, Watkins S, Laird AD, Wolf SF, Gorelik E. 2002. Combined therapy of local and metastatic 4T1 breast tumor in mice using SU6668, an inhibitor of angiogenic receptor tyrosine kinases, and the immunostimulator B7.2-IgG fusion protein. Cancer Res 62: 5727-5735.

Huang H, Bhat A, Woodnutt G, Lappe R. 2010. Targeting the ANGPT-TIE2 pathway in malignancy. Nat Rev Cancer 10: 575-585.

Huang Y, Snuderl M, Jain RK. 2011. Polarization of tumorassociated macrophages: a novel strategy for vascular normalization and antitumor immunity. Cancer Cell 19: $1-2$.

Hurwitz H, Fehrenbacher L, Novotny W, Cartwright T, Hainsworth J, Heim W, Berlin J, Baron A, Griffing S, Holmgren E, et al. 2004. Bevacizumab plus irinotecan, fluorouracil, and leucovorin for metastatic colorectal cancer. N Engl J Med 350: 2335-2342.

Ide AG, Baker NH, Warren SL. 1939. Vascularization of the Brown-Pearce rabbit epithelioma transplant as seen in the transparent ear chamber. Am J Radiol 42: 891-899.

Inai T, Mancuso $\mathrm{M}$, Hashizume $\mathrm{H}$, Baffert $\mathrm{F}$, Haskell $\mathrm{A}$, Baluk P, Hu-Lowe DD, Shalinsky DR, Thurston G,
Yancopoulos GD, et al. 2004. Inhibition of vascular endothelial growth factor (VEGF) signaling in cancer causes loss of endothelial fenestrations, regression of tumor vessels, and appearance of basement membrane ghosts. Am J Pathol 165: 35-52.

Ishida S, Usui T, Yamashiro K, Kaji Y, Amano S, Ogura Y, Hida T, Oguchi Y, Ambati J, Miller JW, et al. 2003. VEGF164-mediated inflammation is required for pathological, but not physiological, ischemia-induced retinal neovascularization. J Exp Med 198: 483-489.

Izumi Y, Xu L, di Tomaso E, Fukumura D, Jain RK. 2002. Tumour biology: Herceptin acts as an anti-angiogenic cocktail. Nature 416: 279-280.

Jain RK. 1988. Determinants of tumor blood flow: A review. Cancer Res 48: 2641-2658.

Jain RK. 1989. Delivery of novel therapeutic agents in tumors: Physiological barriers and strategies. J Natl Cancer Inst 81: 570-576.

Jain RK. 2001. Normalizing tumor vasculature with antiangiogenic therapy: A new paradigm for combination therapy. Nat Med 7: 987-989.

Jain RK. 2003. Molecular regulation of vessel maturation. Nat Med 9: 685-693.

Jain RK. 2005a. Antiangiogenic therapy for cancer: Current and emerging concepts. Oncology (Williston Park) 19: 7-16.

Jain RK. 2005b. Normalization of tumor vasculature: An emerging concept in antiangiogenic therapy. Science 307: $58-62$.

Jain RK. 2008. Taming vessels to treat cancer. Sci Am 298: $56-63$.

Jain RK, Booth MF. 2003. What brings pericytes to tumor vessels? J Clin Invest 112: 1134-1136.

Jain RK, Safabakhsh N, Sckell A, Chen Y, Jiang P, Benjamin L, Yuan F, Keshet E. 1998. Endothelial cell death, angiogenesis, and microvascular function after castration in an androgen-dependent tumor: Role of vascular endothelial growth factor. Proc Natl Acad Sci 95: 10820-10825.

Jain RK, Duda DG, Clark JW, Loeffler JS. 2006. Lessons from phase III clinical trials on anti-VEGF therapy for cancer. Nat Clin Pract Oncol 3: 24-40.

Jain RK, Finn AV, Kolodgie FD, Gold HK, Virmani R. 2007. Antiangiogenic therapy for normalization of atherosclerotic plaque vasculature: A potential strategy for plaque stabilization. Nat Clin Pract Cardiovasc Med 4: 491-502.

Jain RK, Duda DG, Willett CG, Sahani DV, Zhu AX, Loeffler JS, Batchelor TT, Sorensen AG. 2009. Biomarkers of response and resistance to antiangiogenic therapy. Nat Rev Clin Oncol 6: 327-338.

Jeziorska M, Woolley DE. 1999. Local neovascularization and cellular composition within vulnerable regions of atherosclerotic plaques of human carotid arteries. $J$ Pathol 188: 189-196.

Johns TG, McKay MJ, Cvrljevic AN, Gan HK, Taylor C, Xu H, Smyth FE, Scott AM. 2010. MAb 806 enhances the efficacy of ionizing radiation in glioma xenografts expressing the de2-7 epidermal growth factor receptor. Int J Radiat Oncol Biol Phys 78: 572-578.

Juan TY, Roffler SR, Hou HS, Huang SM, Chen KC, Leu YL, Prijovich ZM, Yu CP, Wu CC, Sun GH, et al. 2009. 
Antiangiogenesis targeting tumor microenvironment synergizes glucuronide prodrug antitumor activity. Clin Cancer Res 15: 4600-4611.

Kamoun WS, Ley CD, Farrar CT, Duyverman AM, Lahdenranta J, Lacorre DA, Batchelor TT, di Tomaso E, Duda DG, Munn LL, et al. 2009. Edema control by cediranib, a vascular endothelial growth factor receptor-targeted kinase inhibitor, prolongs survival despite persistent brain tumor growth in mice. J Clin Oncol 27: 2542-2552.

Kamoun WS, Chae SS, Lacorre DA, Tyrrell JA, Mitre M, Gillissen MA, Fukumura D, Jain RK, Munn LL. 2010. Simultaneous measurement of RBC velocity, flux, hematocrit and shear rate in vascular networks. Nat Methods 7: $655-660$.

Kashiwagi S, Izumi Y, Gohongi T, Demou ZN, Xu L, Huang PL, Buerk DG, Munn LL, Jain RK, Fukumura D. 2005 NO mediates mural cell recruitment and vessel morphogenesis in murine melanomas and tissue-engineered blood vessels. J Clin Invest 115: 1816-1827.

Kashiwagi S, Tsukada K, Xu L, Miyazaki J, Kozin SV, Tyrrell JA, Sessa WC, Gerweck LE, Jain RK, Fukumura D. 2008. Perivascular nitric oxide gradients normalize tumor vasculature. Nat Med 14: 255-257.

Kerbel RS, Kamen BA. 2004. The anti-angiogenic basis of metronomic chemotherapy. Nat Rev Cancer 4: 423-436.

Keshtgarpour M, Dudek AZ. 2007. SU-011248, a vascular endothelial growth factor receptor-tyrosine kinase inhibitor, controls chronic psoriasis. Trans Res 149: 103-106.

Kim KJ, Li B, Winer J, Armanini M, Gillett N, Phillips HS, Ferrara N. 1993. Inhibition of vascular endothelial growth factor-induced angiogenesis suppresses tumour growth in vivo. Nature 362: 841-844.

Koh YJ, Kim HZ, Hwang SI, Lee JE, Oh N, Jung K, Kim M, Kim KE, Kim H, Lim NK, et al. 2010. Double antiangiogenic protein, DAAP, targeting VEGF-A and angiopoietins in tumor angiogenesis, metastasis, and vascular leakage. Cancer Cell 18: 171-184.

Kolodgie FD, Gold HK, Burke AP, Fowler DR, Kruth HS, Weber DK, Farb A, Guerrero LJ, Hayase M, Kutys R, et al. 2003. Intraplaque hemorrhage and progression of coronary atheroma. N Engl J Med 349: 2316-2325.

Kozin SV, Boucher Y, Hicklin DJ, Bohlen P, Jain RK, Suit HD. 2001. Vascular endothelial growth factor receptor-2blocking antibody potentiates radiation-induced longterm control of human tumor xenografts. Cancer Res 61: $39-44$.

Kurozumi K, Hardcastle J, Thakur R, Yang M, Christoforidis G, Fulci G, Hochberg FH, Weissleder R, Carson W, Chiocca EA, et al. 2007. Effect of tumor microenvironment modulation on the efficacy of oncolytic virus therapy. J Natl Cancer Inst 99: 1768-1781.

Lebrin F, Srun S, Raymond K, Martin S, van den Brink S, Freitas C, Breant C, Mathivet T, Larrivee B, Thomas JL, et al. 2010. Thalidomide stimulates vessel maturation and reduces epistaxis in individuals with hereditary hemorrhagic telangiectasia. Nat Med 16: 420-428.

Lee CG, Heijn M, di Tomaso E, Griffon-Etienne G, Ancukiewicz M, Koike C, Park KR, Ferrara N, Jain RK, Suit HD, et al. 2000. Anti-Vascular endothelial growth factor treatment augments tumor radiation response under normoxic or hypoxic conditions. Cancer Res 60: 5565-5570.
Less JR, Skalak TC, Sevick EM, Jain RK. 1991. Microvascular architecture in a mammary carcinoma: Branching patterns and vessel dimensions. Cancer Res 51: 265-273.

Less JR, Posner MC, Boucher Y, Borochovitz D, Wolmark N, Jain RK. 1992. Interstitial hypertension in human breast and colorectal tumors. Cancer Res 52: 6371-6374.

Less JR, Posner MC, Skalak TC, Wolmark N, Jain RK. 1997. Geometric resistance and microvascular network architecture of human colorectal carcinoma. Microcirculation 4: $25-33$.

Leung DW, Cachianes G, Kuang WJ, Goeddel DV, Ferrara N. 1989. Vascular endothelial growth factor is a secreted angiogenic mitogen. Science 246: 1306-1309.

Leunig M, Yuan F, Menger MD, Boucher Y, Goetz AE, Messmer K, Jain RK. 1992. Angiogenesis, microvascular architecture, microhemodynamics, and interstitial fluid pressure during early growth of human adenocarcinoma LS174T in SCID mice. Cancer Res 52: 6553-6560.

Li B, Lalani AS, Harding TC, Luan B, Koprivnikar K, Huan Tu G, Prell R, VanRoey MJ, Simmons AD, et al. 2006. Vascular endothelial growth factor blockade reduces intratumoral regulatory $\mathrm{T}$ cells and enhances the efficacy of a GM-CSF-secreting cancer immunotherapy. Clin Cancer Res 12: 6808-6816.

Liao S, Liu J, Lin P, Jain RK, Xu L. 2011. TGF- $\beta$ blockade controls ascites by preventing abnormalization of lymphatic vessels in an orthotopic human ovarian carcinoma models. Clin Cancer Res 17: 1415-1424.

Liu F, Wang P, Jiang X, Tan G, Qiao H, Jiang H, Krissansen GW, Sun X. 2008. Antisense hypoxia-inducible factor $1 \alpha$ gene therapy enhances the therapeutic efficacy of doxorubicin to combat hepatocellular carcinoma. Cancer Sci 99: 2055-2061.

Lu-Emerson C, Plotkin SR. 2009. The neurofibromatoses. Part 2: NF2 and schwannomatosis. Rev Neurol Dis 6: E81-E86.

Maione F, Molla F, Meda C, Latini R, Zentilin L, Giacca M, Seano G, Serini G, Bussolino F, Giraudo E. 2009. Semaphorin $3 \mathrm{~A}$ is an endogenous angiogenesis inhibitor that blocks growth and normalizes the vasculature. J Clin Invest 119: 3356-3372.

Manning EA, Ullman JG, Leatherman JM, Asquith JM, Hansen TR, Armstrong TD, Hicklin DJ, Jaffee EM, Emens LA. 2007. A vascular endothelial growth factor receptor-2 inhibitor enhances antitumor immunity through an immune-based mechanism. Clin Cancer Res 13: 3951-3959.

Mazzieri R, Pucci F, Moi D, Zonari E, Ranghetti A, Berti A, Pliti LS, Gentner B, Brown JL, Naldini L, De Palma M. 2011. Targeting the ANG2/TIE2 axis inhibits tumor growth and metastasis by impairing angiogenesis and disabling rebounds of proangiogenic myeloid cells. Cancer Cell 19: 512-526.

Mazzone M, Dettori D, Leite de Oliveira R, Loges S, Schmidt T, Jonckx B, Tian YM, Lanahan AA, Pollard P, Ruiz de Almodovar C, et al. 2009. Heterozygous deficiency of PHD2 restores tumor oxygenation and inhibits metastasis via endothelial normalization [see comment]. Cell 136: 839-851.

McCarty MF, Somcio RJ, Stoeltzing O, Wey J, Fan F, Liu W, Bucana C, Ellis LM. 2007. Overexpression of PDGF-BB decreases colorectal and pancreatic cancer growth by 
S. Goel et al.

increasing tumor pericyte content. J Clin Invest 117: 2114-2122.

McGee MC, Hamner JB, Williams RF, Rosati SF, Sims TL, Ng CY, Gaber MW, Calabrese C, Wu J, Nathwani AC, et al. 2010. Improved intratumoral oxygenation through vascular normalization increases glioma sensitivity to ionizing radiation. Int J Radiat Oncol Biol Phys 76: 1537-1545.

Miller K, Wang M, Gralow J, Dickler M, Cobleigh M, Perez EA, Shenkier T, Cella D, Davidson NE. 2007. Paclitaxel plus bevacizumab versus paclitaxel alone for metastatic breast cancer. $N$ Engl J Med 357: 2666-2676.

Morikawa S, Baluk P, Kaidoh T, Haskell A, Jain RK, McDonald DM. 2002. Abnormalities in pericytes on blood vessels and endothelial sprouts in tumors. Am J Pathol 160: 985-1000

Moulton KS, Heller E, Konerding MA, Flynn E, Palinski W, Folkman J. 1999. Angiogenesis inhibitors endostatin or TNP-470 reduce intimal neovascularization and plaque growth in apolipoprotein E-deficient mice. Circulation 99: $1726-1732$.

Nagy JA, Chang SH, Dvorak AM, Dvorak HF. 2009. Why are tumour blood vessels abnormal and why is it important to know? Br J Cancer 100: 865-869.

Nakahara T, Norberg SM, Shalinsky DR, Hu-Lowe DD, McDonald DM. 2006. Effect of inhibition of vascular endothelial growth factor signaling on distribution of extravasated antibodies in tumors. Cancer Res 66: 1434-1445.

Narayanan S, Callis-Duffin K, Batten J, Agarwal N. 2010. Improvement of psoriasis during sunitinib therapy for renal cell carcinoma. Am J Med Sci 339: 580-581.

Nasarre P, Thomas M, Kruse K, Helfrich I, Wolter V, Deppermann C, Schadendorf D, Thurston G, Fiedler U, Augustin HG. 2009. Host-derived angiopoietin-2 affects early stages of tumor development and vessel maturation but is dispensable for later stages of tumor growth. Cancer Res 69: 1324-1333.

Ohta M, Kawabata T, Yamamoto M, Tanaka T, Kikuchi H, Hiramatsu Y, Kamiya K, Baba M, Konno H. 2009. TSU68, an antiangiogenic receptor tyrosine kinase inhibitor, induces tumor vascular normalization in a human cancer xenograft nude mouse model. Surg Today 39: 1046-1053.

Padera TP, Stoll BR, Tooredman JB, Capen D, di Tomaso E, Jain RK. 2004. Pathology: Cancer cells compress intratumour vessels. Nature 427: 695.

Paez-Ribes M, Allen E, Hudock J, Takeda T, Okuyama H, Vinals F, Inoue M, Bergers G, Hanahan D, Casanovas O. 2009. Antiangiogenic therapy elicits malignant progression of tumors to increased local invasion and distant metastasis. Cancer Cell 15: 220-231.

Plotkin SR, Stemmer-Rachamimov AO, Barker FG, 2nd, Halpin C, Padera TP, Tyrrell A, Sorensen AG, Jain RK, di Tomaso E. 2009. Hearing improvement after bevacizumab in patients with neurofibromatosis type $2 . N$ Engl J Med 361: 358-367.

Pore N, Gupta AK, Cerniglia GJ, Jiang Z, Bernhard EJ, Evans SM, Koch CJ, Hahn SM, Maity A. 2006a. Nelfinavir down-regulates hypoxia-inducible factor $1 \alpha$ and VEGF expression and increases tumor oxygenation: implications for radiotherapy. Cancer Res 66: 9252-9259.
Pore N, Jiang Z, Gupta A, Cerniglia G, Kao GD, Maity A. 2006b. EGFR tyrosine kinase inhibitors decrease VEGF expression by both hypoxia-inducible factor (HIF)-1independent and HIF-1-dependent mechanisms. Cancer Res 66: 3197-3204.

Primo L, Seano G, Roca C, Maione F, Gagliardi PA, Sessa R, Martinelli M, Giraudo E, di Blasio L, Bussolino F. 2010. Increased expression of $\alpha 6$ integrin in endothelial cells unveils a proangiogenic role for basement membrane. Cancer Res 70: 5759-5769.

Qayum N, Muschel RJ, Im JH, Balathasan L, Koch CJ, Patel S, McKenna WG, Bernhard EJ. 2009. Tumor vascular changes mediated by inhibition of oncogenic signaling. Cancer Res 69: 6347-6354.

Rajappa M, Saxena P, Kaur J. 2010. Ocular angiogenesis: mechanisms and recent advances in therapy. Adv Clin Chem 50: 103-121.

Reck M, von Pawel J, Zatloukal P, Ramlau R, Gorbounova V, Hirsh V, Leighl N, Mezger J, Archer V, Moore N, et al. 2009. Phase III trial of cisplatin plus gemcitabine with either placebo or bevacizumab as first-line therapy for nonsquamous non-small-cell lung cancer: AVAil. J Clin Oncol 27: $1227-1234$.

Roh HD, Boucher Y, Kalnicki S, Buchsbaum R, Bloomer WD, Jain RK. 1991. Interstitial hypertension in carcinoma of uterine cervix in patients: Possible correlation with tumor oxygenation and radiation response. Cancer Res 51: 6695-6698.

Rolny C, Mazzone M, Tugues S, Laoui D, Johannson I, Couon C, Squadrito ML, Segura I, Li X, Knevels E, et al. 2011. HRG inhibits tumor growth and metastasis by inducing macrophage polarization and vessel normalization through downregulation of PlGF. Cancer Cell 19: $31-44$.

Rosenfeld PJ, Brown DM, Heier JS, Boyer DS, Kaiser PK, Chung CY, Kim RY. 2006. Ranibizumab for neovascular age-related macular degeneration. $N$ Engl J Med 355: 1419-1431.

Salnikov AV, Roswall P, Sundberg C, Gardner H, Heldin NE, Rubin K. 2005. Inhibition of TGF- $\beta$ modulates macrophages and vessel maturation in parallel to a lowering of interstitial fluid pressure in experimental carcinoma. Lab Invest 85: 512-521.

Saltz LB, Clarke S, Diaz-Rubio E, Scheithauer W, Figer A, Wong R, Koski S, Lichinitser M, Yang TS, Rivera F, et al. 2008. Bevacizumab in combination with oxaliplatin-based chemotherapy as first-line therapy in metastatic colorectal cancer: a randomized phase III study. $J$ Clin Oncol 26: 2013-2019.

Sandler A, Gray R, Perry MC, Brahmer J, Schiller JH, Dowlati A, Lilenbaum R, Johnson DH. 2006. Paclitaxelcarboplatin alone or with bevacizumab for non-smallcell lung cancer. N Engl J Med 355: 2542-2550.

Schnell CR, Stauffer F, Allegrini PR, O’Reilly T, McSheehy PM, Dartois C, Stumm M, Cozens R, Littlewood-Evans A, Garcia-Echeverria C, et al. 2008. Effects of the dual phosphatidylinositol 3-kinase/mammalian target of rapamycin inhibitor NVP-BEZ235 on the tumor vasculature: Implications for clinical imaging. Cancer Res 68: 6598-6607.

Schonthaler HB, Huggenberger R, Wculek SK, Detmar M, Wagner EF. 2009. Systemic anti-VEGF treatment strongly 
reduces skin inflammation in a mouse model of psoriasis. Proc Natl Acad Sci 106: 21264-21269.

Segers J, Di Fazio V, Ansiaux R, Martinive P, Feron O, Wallemacq P, Gallez B. 2006. Potentiation of cyclophosphamide chemotherapy using the anti-angiogenic drug thalidomide: importance of optimal scheduling to exploit the "normalization" window of the tumor vasculature. Cancer Lett 244: 129-135.

Semenza GL. 2010. Defining the role of hypoxia-inducible factor 1 in cancer biology and therapeutics. Oncogene 29: 625-634.

Senger DR, Galli SJ, Dvorak AM, Perruzzi CA, Harvey VS, Dvorak HF. 1983. Tumor cells secrete a vascular permeability factor that promotes accumulation of ascites fluid. Science 219: 983-985.

Shrimali RK, Yu Z, Theoret MR, Chinnasamy D, Restifo NP, Rosenberg SA. 2010. Antiangiogenic agents can increase lymphocyte infiltration into tumor and enhance the effectiveness of adoptive immunotherapy of cancer. Cancer Res 70: 6171-6180.

Skuli N, Monferran S, Delmas C, Favre G, Bonnet J, Toulas C, Cohen-Jonathan Moyal E. 2009. $\alpha v \beta 3 / \alpha v \beta 5$ integrins-FAK-RhoB: A novel pathway for hypoxia regulation in glioblastoma. Cancer Res 69: 3308-3316.

Sorensen AG, Batchelor TT, Zhang WT, Chen PJ, Yeo P, Wang M, Jennings D, Wen PY, Lahdenranta J, Ancukiewicz M, et al. 2009. A "vascular normalization index" as potential mechanistic biomarker to predict survival after a single dose of cediranib in recurrent glioblastoma patients. Cancer Res 69: 5296-5300.

Stockmann C, Doedens A, Weidemann A, Zhang N, Takeda N, Greenberg JI, Cheresh DA, Johnson RS. 2008. Deletion of vascular endothelial growth factor in myeloid cells accelerates tumorigenesis. Nature 456: 814-818.

Stohrer M, Boucher Y, Stangassinger M, Jain RK. 2000. Oncotic pressure in solid tumors is elevated. Cancer Res 60: $4251-4255$.

Suri C, Jones PF, Patan S, Bartunkova S, Maisonpierre PC, Davis S, Sato TN, Yancopoulos GD. 1996. Requisite role of angiopoietin-1, a ligand for the TIE2 receptor, during embryonic angiogenesis. Cell 87: 1171-1180.

Taguchi E, Nakamura K, Miura T, Shibuya M, Isoe T. 2008. Anti-tumor activity and tumor vessel normalization by the vascular endothelial growth factor receptor tyrosine kinase inhibitor KRN951 in a rat peritoneal disseminated tumor model. Cancer Sci 99: 623-630.

Taylor KL, Leaman DW, Grane R, Mechti N, Borden EC Lindner DJ. 2008. Identification of interferon- $\beta$-stimulated genes that inhibit angiogenesis in vitro. J Interferon Cytokine Res 28: 733-740.

Teicher BA. 1996. A systems approach to cancer therapy (antioncogenics + standard cytotoxics $\rightarrow$ mechanism(s) of interaction). Cancer Metastasis Rev 15: 247-272.

Teicher BA, Dupuis NP, Robinson MF, Emi Y, Goff DA. 1995a. Antiangiogenic treatment (TNP-470/minocycline) increases tissue levels of anticancer drugs in mice bearing Lewis lung carcinoma. Oncol Res 7: 237-243.

Teicher BA, Holden SA, Dupuis NP, Kakeji Y, Ikebe M, Emi Y, Goff D. 1995b. Potentiation of cytotoxic therapies by TNP-470 and minocycline in mice bearing EMT-6 mammary carcinoma. Breast Cancer Res Treat 36: 227-236.

Thurston G, Suri C, Smith K, McClain J, Sato TN, Yancopoulos GD, McDonald DM. 1999. Leakage-resistant blood vessels in mice transgenically overexpressing angiopoietin-1. Science 286: 2511-2514.

Thurston G, Rudge JS, Ioffe E, Zhou H, Ross L, Croll SD, Glazer N, Holash J, McDonald DM, Yancopoulos GD. 2000. Angiopoietin-1 protects the adult vasculature against plasma leakage. Nature Med 6: 460-463.

Tong RT, Boucher Y, Kozin SV, Winkler F, Hicklin DJ, Jain RK. 2004. Vascular normalization by vascular endothelial growth factor receptor 2 blockade induces a pressure gradient across the vasculature and improves drug penetration in tumors. Cancer Res 64: 3731-3736.

Tsukada K, Conner D, Lin Q, Kucherlapati R, Jain RK, Fukumura D. 2009. Blockade of inducible nitric oxide synthase normalizes murine breast cancer vessels. In 100th Annual Meeting of AACR, Denver, CO.

Van de Veire S, Stalmans I, Heindryckx F, Oura H, TijerasRaballand A, Schmidt T, Loges S, Albrecht I, Jonckx B, Vinckier S, et al. 2010. Further pharmacological and genetic evidence for the efficacy of PlGF inhibition in cancer and eye disease. Cell 141: 178-190.

Virmani R, Kolodgie FD, Burke AP, Finn AV, Gold HK, Tulenko TN, Wrenn SP, Narula J. 2005. Atherosclerotic plaque progression and vulnerability to rupture: angiogenesis as a source of intraplaque hemorrhage. Arterioscler Thromb Vasc Biol 25: 2054-2061.

Vogelstein B, Kinzler KW. 2004. Cancer genes and the pathways they control. Nat Med 10: 789-799.

Wildiers H, Guetens G, De Boeck G, Verbeken E, Landuyt B, Landuyt W, de Bruijn EA, van Oosterom AT. 2003. Effect of antivascular endothelial growth factor treatment on the intratumoral uptake of CPT-11. Br J Cancer 88: 1979-1986.

Willett CG, Boucher Y, di Tomaso E, Duda DG, Munn LL, Tong RT, Chung DC, Sahani DV, Kalva SP, Kozin SV, et al. 2004. Direct evidence that the VEGF-specific antibody bevacizumab has antivascular effects in human rectal cancer. Nat Med 10: 145-147.

Willett CG, Boucher Y, Duda DG, di Tomaso E, Munn LL, Tong RT, Kozin SV, Petit L, Jain RK, Chung DC, et al. 2005. Surrogate markers for antiangiogenic therapy and dose-limiting toxicities for bevacizumab with radiation and chemotherapy: Continued experience of a phase I trial in rectal cancer patients. J Clin Oncol 23: 8136-8139.

Willett CG, Duda DG, di Tomaso E, Boucher Y, Ancukiewicz M, Sahani DV, Lahdenranta J, Chung DC, Fischman AJ, Lauwers GY, et al. 2009. Efficacy, safety, and biomarkers of neoadjuvant bevacizumab, radiation therapy, and fluorouracil in rectal cancer: A multidisciplinary phase II study. J Clin Oncol 27: 3020-3026.

Winkler F, Kozin SV, Tong RT, Chae SS, Booth MF, Garkavtsev I, Xu L, Hicklin DJ, Fukumura D, di Tomaso E, et al. 2004. Kinetics of vascular normalization by VEGFR2 blockade governs brain tumor response to radiation: role of oxygenation, angiopoietin- 1 , and matrix metalloproteinases [see comment]. Cancer Cell 6: $553-563$. 
S. Goel et al.

Wong HK, Lahdenranta J, Kamoun WS, Chan AW, McClatchey AI, Plotkin SR, Jain RK, di Tomaso E. 2010. Anti-vascular endothelial growth factor therapies as a novel therapeutic approach to treating neurofibromatosis-related tumors. Cancer Res 70: 3483-3493.

Xian X, Hakansson J, Stahlberg A, Lindblom P, Betsholtz C, Gerhardt H, Semb H. 2006. Pericytes limit tumor cell metastasis. J Clin Invest 116: 642-651.

Xue Q, Hopkins B, Perruzzi C, Udayakumar D, Sherris D, Benjamin LE. 2008. Palomid 529, a novel small-molecule drug, is a TORC1/TORC2 inhibitor that reduces tumor growth, tumor angiogenesis, and vascular permeability. Cancer Res 68: 9551-9557.

Yu J, deMuinck ED, Zhuang Z, Drinane M, Kauser K, Rubanyi GM, Qian HS, Murata T, Escalante B, Sessa WC. 2005. Endothelial nitric oxide synthase is critical for ischemic remodeling, mural cell recruitment, and blood flow reserve. Proc Natl Acad Sci 102: 10999-11004.
Yuan F, Chen Y, Dellian M, Safabakhsh N, Ferrara N, Jain RK. 1996. Time-dependent vascular regression and permeability changes in established human tumor xenografts induced by an anti-vascular endothelial growth factor/vascular permeability factor antibody. Proc Natl Acad Sci 93: 14765-14770.

Zhou Q, Gallo JM. 2009. Differential effect of sunitinib on the distribution of temozolomide in an orthotopic glioma model. Neuro-Oncology 11: 301-310.

Zhou Q, Guo P, Gallo JM. 2008. Impact of angiogenesis inhibition by sunitinib on tumor distribution of temozolomide [erratum appears in Clin Cancer Res, 2008 Aug 15;14(16):5308-9]. Clin Cancer Res 14: 1540-1549.

Zibert JR, Wallbrecht K, Schon M, Mir LM, Jacobsen GK, Trochon-Joseph V, Bouquet C, Villadsen LS, Cadossi R, Skov L, et al. 2010. Halting angiogenesis by non-viral somatic gene therapy alleviates psoriasis and murine psoriasiform skin lesions. J Clin Invest 121: 410-421. 


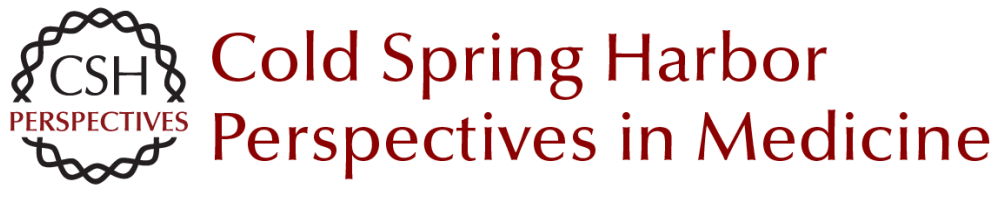

\title{
Vascular Normalization as a Therapeutic Strategy for Malignant and Nonmalignant Disease
}

\author{
Shom Goel, Andus Hon-Kit Wong and Rakesh K. Jain
}

Cold Spring Harb Perspect Med 2012; doi: 10.1101/cshperspect.a006486 originally published online October 18, 2011

\section{Subject Collection Angiogenesis}

\section{Extracellular Matrix Regulation of Vascular}

Morphogenesis, Maturation, and Stabilization George E. Davis and Scott S. Kemp

Endothelial Cell-Pericyte Interactions in the

Pathogenesis of Cerebral Cavernous

Malformations (CCMs)

Wang Min and Jenny Huanjiao Zhou

Lymphatic Clearance and Pump Function Jerome W. Breslin

Platelets and (Lymph)angiogenesis Harvey G. Roweth and Elisabeth M. Battinelli

Modeling Brain Vasculature Immune Interactions In Vitro

Ruth Lyck, Hideaki Nishihara, Sidar Aydin, et al.

Human Endothelial Colony-Forming Cells Juan M. Melero-Martin

The Beauty and Complexity of Blood Vessel Patterning

Victoria L. Bautch and Yoh-suke Mukouyama

Endothelialitis, Microischemia, and

Intussusceptive Angiogenesis in COVID-19

Steven J. Mentzer, Maximilian Ackermann and

Danny Jonigk
Regulation of the Blood-Brain Barrier in Health and Disease

Cara C. Rada, Kanako Yuki, Jie Ding, et al.

Targeting Angiogenesis via Resolution of Inflammation

Abigail G. Kelly and Dipak Panigrahy

Notch Signaling in the Vasculature: Angiogenesis and Angiocrine Functions

Sana S. Hasan and Andreas Fischer

Signal Transduction and Gene Regulation in the

Endothelium

Michel V. Levesque and Timothy Hla

Buttons and Zippers: Endothelial Junctions in

Lymphatic Vessels

Peter Baluk and Donald M. McDonald

Endothelial Cell Fate Determination: A Top Notch Job in Vascular Decision-Making

L.A. Naiche, Stephanie R. Villa and Jan K. Kitajewski

Leukocyte Trafficking in Lymphatic Vessels Aline Bauer, Hazal Tatliadim and Cornelia Halin

Lymphatic Tissue and Organ Engineering for In Vitro Modeling and In Vivo Regeneration Anna M. Kolarzyk, Gigi Wong and Esak Lee

For additional articles in this collection, see http://perspectivesinmedicine.cshlp.org/cgi/collection/ 